\title{
Depleted Uranium \\ Plasma Reduction System Study
}

\author{
Pete Rekemeyer ${ }^{\mathrm{a}}$ \\ Fred Feizollahi ${ }^{\mathrm{a}}$ \\ William J. Quapp \\ Blaine W. Brown
}

Published December 1994
Idaho National Engineering Laboratory Lockheed Idaho Technologies Company Idaho Falls, Idaho $\mathbf{8 3 4 1 5}$

Prepared for the

U.S. Department of Energy

Assistant Secretary for Environmental Management Under DOE Idaho Operations Office

Contract DE-AC07-94ID13223

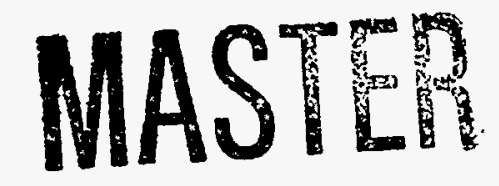

a. Engineering, Construction, \& Environmental Group, Morrison Knudsen Corporation. 
ห.

3 


\section{DISCLAIMER}

This report was prepared as an account of work sponsored by an agency of the United States Government. Neither the United States Government nor any agency thereof, nor any of their employees, make any warranty, express or implied, or assumes any legal liability or responsibility for the accuracy, completeness, or usefulness of any information, apparatus, product, or process disclosed, or represents that its use would not infringe privately owned rights. Reference herein to any specific commercial product, process, or service by trade name, trademark, manufacturer, or otherwise does not necessarily constitute or imply its endorsement, recommendation, or favoring by the United States Government or any agency thereof. The views and opinions of authors expressed herein do not necessarily state or reflect those of the United States Government or any agency thereof. 


\section{DISCLAIMER}

Portions of this document may be illegible in electronic image products. Images are produced from the best available original document. 


\title{
Depleted Uranium Plasma Reduction System Study
}

\author{
INEL-94/0030
}

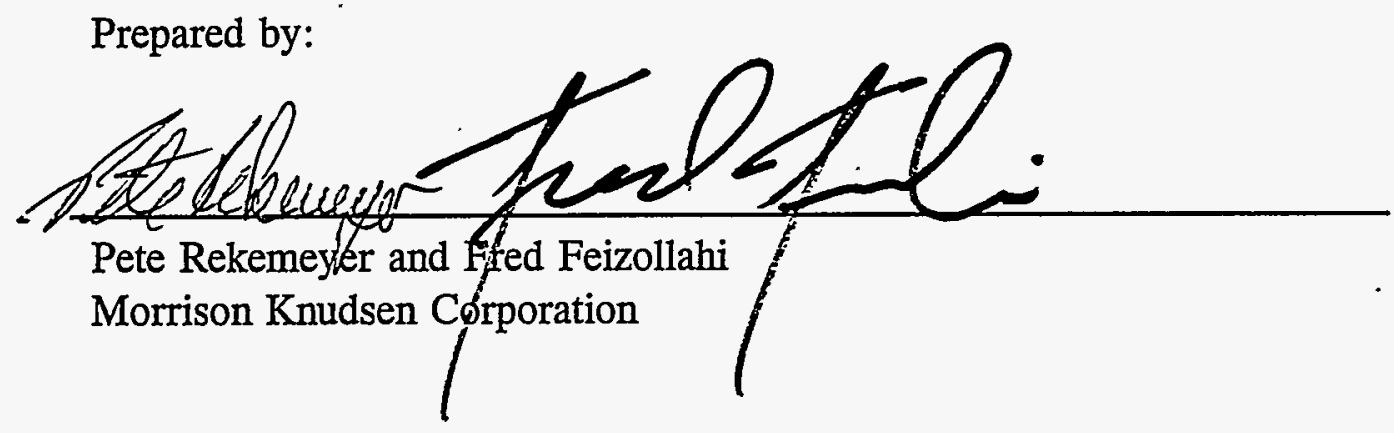

Date

Reviewed and Approved by:

Blainew Brom

Blaine W. Brown, Sr., Engineering Specialist

Depleted Uranium Recycle Project
$12-15-94$

Date

Reviewed and Approved by:

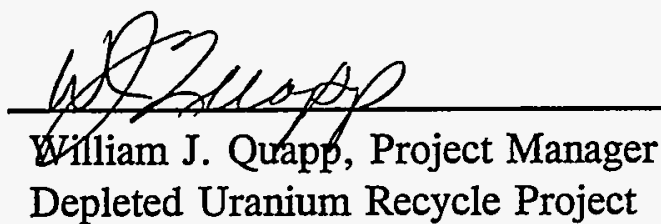

$\frac{12-5-94}{\text { Date }}$ 


\section{ABSTRACT}

A system life-cycle cost study was conducted of a preliminary design concept for a plasma reduction process for converting depleted uranium to uranium metal and anhydrous HF. The plasmabased process is expected to offer significant economic and environmental advantages over present technology. Depleted Uranium is currently stored in the form of solid $\mathrm{UF}_{6}$, of which approximately 575,000 metric tons is stored at three locations in the U.S. The proposed system is preconceptual in nature, but includes all necessary processing equipment and facilities to perform the process. The study has identified total processing costs of approximately $\$ 3.00 / \mathrm{kg}$ of $\mathrm{UF}_{6}$ processed. Based on the results of this study, the development of a laboratory-scale system (1 kg/h throughput of UF6) is warranted. Further scaling of the process to pilot scale will be determined after laboratory testing is complete. 


\section{ACKNOWLEDGMENTS}

The authors are grateful to Joe Foldyna, Joyce Fabre, and David Bean of the Morrison Knudsen Corporation in Boise for their help in designing the process and in preparing this report. 



\section{CONTENTS}

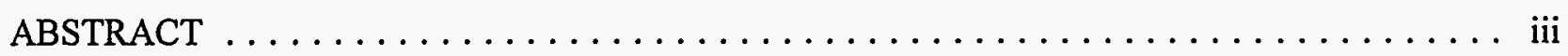

ACKNOWLEDGMENTS $\ldots \ldots \ldots \ldots \ldots \ldots \ldots \ldots \ldots \ldots \ldots \ldots \ldots \ldots \ldots \ldots \ldots \ldots$

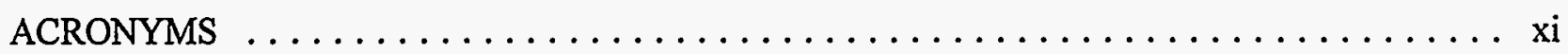

1. INTRODUCTION $\ldots \ldots \ldots \ldots \ldots \ldots \ldots \ldots \ldots \ldots \ldots \ldots \ldots \ldots \ldots \ldots \ldots \ldots \ldots$

1.1 Background $\ldots \ldots \ldots \ldots \ldots \ldots \ldots \ldots \ldots \ldots \ldots \ldots \ldots \ldots \ldots \ldots \ldots \ldots \ldots \ldots$

1.2 Technical Approach $\ldots \ldots \ldots \ldots \ldots \ldots \ldots \ldots \ldots \ldots \ldots \ldots \ldots \ldots \ldots \ldots \ldots \ldots$

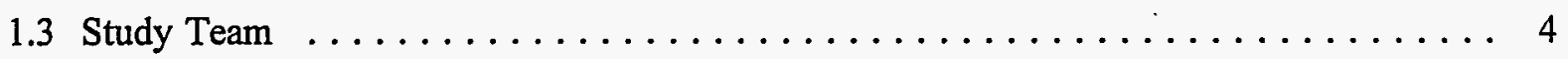

1.4 Key Assumptions $\ldots \ldots \ldots \ldots \ldots \ldots \ldots \ldots \ldots \ldots \ldots \ldots \ldots \ldots$

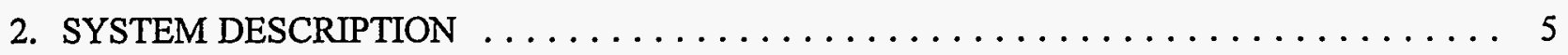

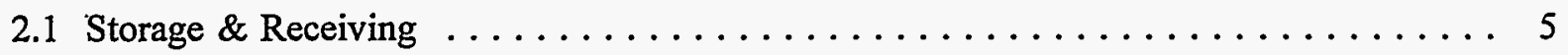

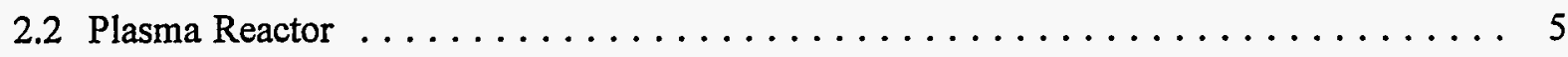

2.3 Metal/Gas Cooling and Separation $\ldots \ldots \ldots \ldots \ldots \ldots \ldots \ldots \ldots \ldots \ldots$

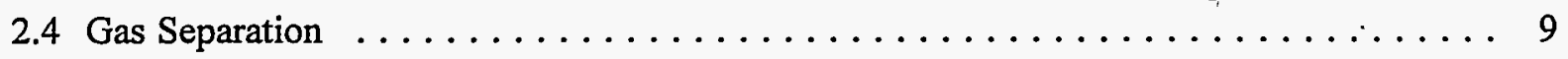

2.5 Uranium Metal Melting $\ldots \ldots \ldots \ldots \ldots \ldots \ldots \ldots \ldots \ldots \ldots$

2.6 Uranium Metal Cutting and Storage $\ldots \ldots \ldots \ldots \ldots \ldots \ldots \ldots \ldots$

2.7 Water Cooling System $\ldots \ldots \ldots \ldots \ldots \ldots \ldots \ldots \ldots \ldots \ldots \ldots \ldots$

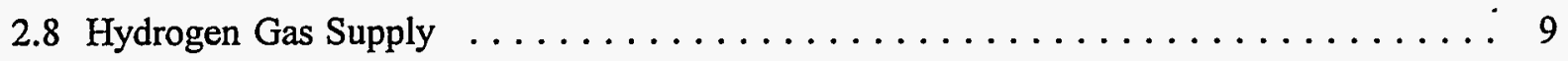

2.9 Electrical \& Motor Control Center $\ldots \ldots \ldots \ldots \ldots \ldots \ldots \ldots \ldots \ldots \ldots \ldots$

2.10 Radiation Monitoring $\ldots \ldots \ldots \ldots \ldots \ldots \ldots \ldots \ldots \ldots \ldots \ldots \ldots \ldots \ldots \ldots \ldots \ldots \ldots$

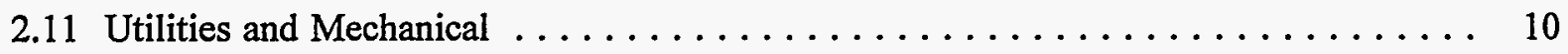

2.12 Administration and Central Control $\ldots \ldots \ldots \ldots \ldots \ldots \ldots \ldots \ldots \ldots \ldots \ldots \ldots \ldots \ldots \ldots$

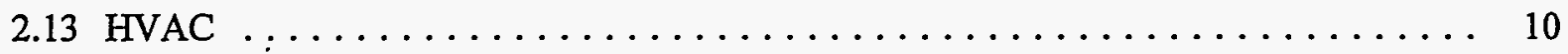

2.14 Civil Construction Work $\ldots \ldots \ldots \ldots \ldots \ldots \ldots \ldots \ldots \ldots \ldots \ldots \ldots \ldots \ldots$ 


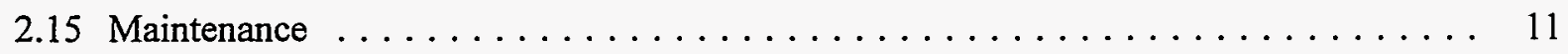

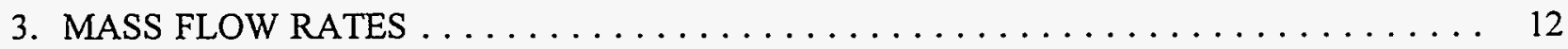

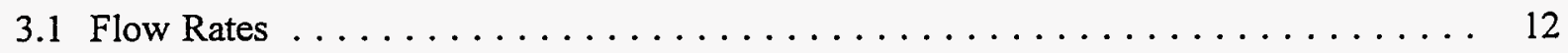

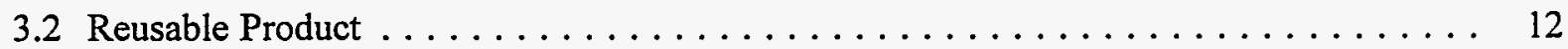

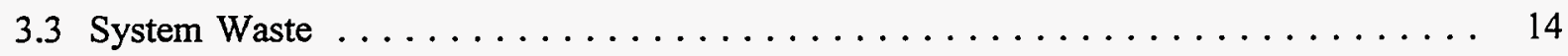

3.4 Key Assumptions for Mass Flow Calculations $\ldots \ldots \ldots \ldots \ldots \ldots \ldots \ldots \ldots \ldots$

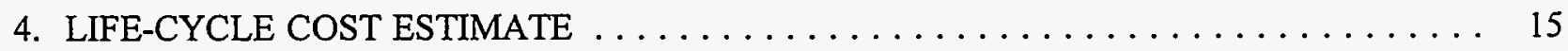

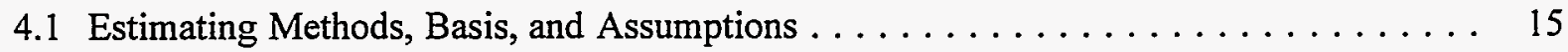

4.2 Treatment Facility PLCC Estimate Summaries $\ldots \ldots \ldots \ldots \ldots \ldots$

4.2.1 Studies and Bench-Scale Tests and Demonstration Tests $\ldots \ldots \ldots \ldots \ldots \ldots$

4.2 .2 Facility Capital Costs . . . . . . . . . . . . . . . . . 20

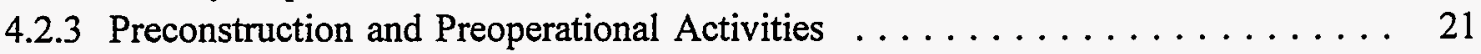

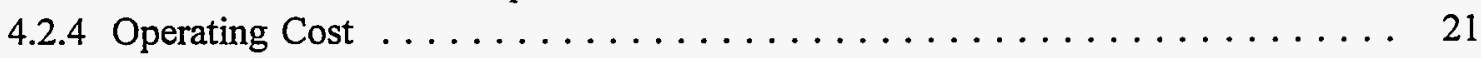

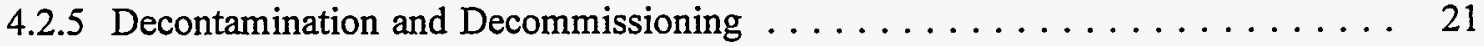

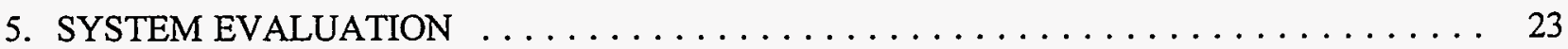

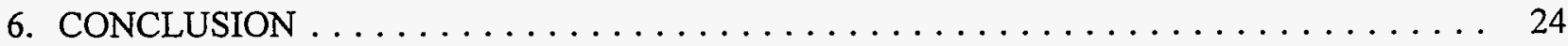

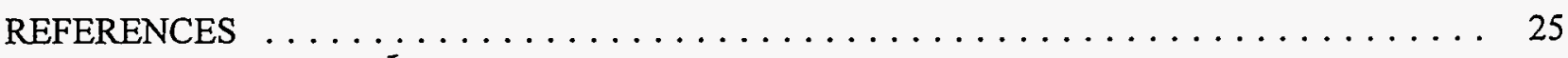

Appendix A Cost Tables $\ldots \ldots \ldots \ldots \ldots \ldots \ldots \ldots \ldots \ldots \ldots \ldots \ldots \ldots \ldots \ldots \ldots \ldots$

\section{FIGURES}

1. $\mathrm{UF}_{6}$ plant flowsheet, plasma quench reduction of $\mathrm{UF}_{6}$ by $\mathrm{H}_{2} \ldots \ldots \ldots \ldots \ldots$

2. Process functional diagram of the DUPRS $\ldots \ldots \ldots \ldots \ldots \ldots \ldots \ldots \ldots \ldots \ldots \ldots \ldots \ldots$

3. Conceptual layout of the DUPRS $\ldots \ldots \ldots \ldots \ldots \ldots \ldots \ldots \ldots \ldots \ldots \ldots \ldots$

4. Perspective view of the DUPRS $\ldots \ldots \ldots \ldots \ldots \ldots \ldots \ldots \ldots \ldots \ldots \ldots \ldots \ldots$

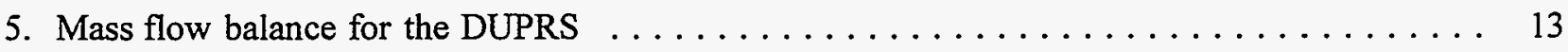

6. Diagram of cost estimating approach $\ldots \ldots \ldots \ldots \ldots \ldots \ldots \ldots \ldots \ldots \ldots \ldots$ 


\section{TABLES}

1. Estimated facility administrative staff $\ldots \ldots \ldots \ldots \ldots \ldots \ldots \ldots \ldots \ldots \ldots \ldots$

2. Amounts to be processed in the various DUPRS areas $\ldots \ldots \ldots \ldots \ldots \ldots \ldots \ldots \ldots \ldots$

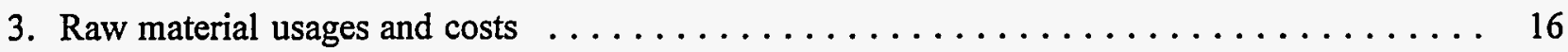

4. ROM life-cycle cost estimate summary for the DUPRS $\ldots \ldots \ldots \ldots \ldots \ldots \ldots$

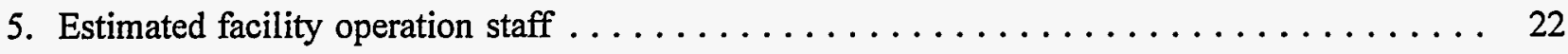





\section{ACRONYMS}

$\mathrm{AC}$

alternating current

$\mathrm{D} \& \mathrm{D}$

decontamination and decommissioning

$\mathrm{DC}$

direct current

DOE

Department of Energy

DUPRS depleted uranium plasma reduction system

ESP

electrostatic precipitator

$\mathrm{HF}$

hydrogen fluoride

HVAC heating, ventilation, and air conditioning

INEL Idaho National Engineering Laboratory

MCC motor control center

MK

Morrison Knudsen Corporation

NEPA National Environmental Policy Act

O\&M operation and maintenance

PLCC project life-cycle cost

ROM rough order of magnitude

SCF $\quad$ standard cubic feet

SCFM standard cubic feet per minute 


\section{Depleted Uranium Plasma Reduction System Study}

\section{INTRODUCTION}

The U.S. Department of Energy's (DOE) Environmental Management Office of Technology Development (EM-50) commissioned this study to examine the feasibility of using the plasma reduction process for converting depleted uranium hexafluoride $\left(\mathrm{UF}_{6}\right)$ to uranium metal ingots. The preconceptual design of the facility for conversion of $\mathrm{UF}_{6}$ to uranium metal was sized to convert an inventory of 4000,000 metric tons over 20 years. After the completion of this study, a better estimate of the DOE UF 6 inventory was developed and found to be nearer 575,000 metric tons. It is estimated that the additional inventory can be processed with a minimal increase in equipment, consumeables, and manpower. Thus, the unit costs determined in this study for processing the 400,000 metric ton inventory should be a bounding estimate if the entire inventory were to be processed in the same time period. This study is part of a larger effort to address possible uses for depleted uranium and examines options to reduce the cost of use.

DOE produced the depleted $\mathrm{UF}_{6}$ in the uranium enrichment process, and has stored it in canisters for up to 50 years at three locations in the U.S. The depleted $\mathrm{UF}_{6}$ contains $0.2 \%{ }^{235} \mathrm{U}$ and uranium decay products, including radon.

\subsection{Background}

$\mathrm{DOE}$ is studying alternative management options for recycling the large quantity of $\mathrm{UF}_{6}$ produced from the uranium enrichment process. The depleted uranium plasma reduction system (DUPRS) could potentially process the stored $\mathrm{UF}_{6}$ and produce uranium metal and hydrogen fluoride (HF). HF is used commercially and uranium metal has potential commercial applications.

This plasma-based process appears to have an economic and environmental advantage over present technology used for $\mathrm{UF}_{6}$ to uranium metal production. The process has successfully been demonstrated in bench-scale tests at the Idaho National Engineering Laboratory (INEL) during FY 1994. This report documents the results of a preconceptual design study that was performed to estimate the production costs of a facility that used the DUPRS to produce uranium metal. This report also contains a preconceptual design of the DUPRS based on the flow diagram in Figure 1 and a brief technical evaluation of the system.

\subsection{Technical Approach}

The DUPRS, illustrated in Figure 1, was divided into 15 unit operations, as follows.

1. Storage and receiving

2. Plasma reactor

3. Metal/gas cooling and separation 


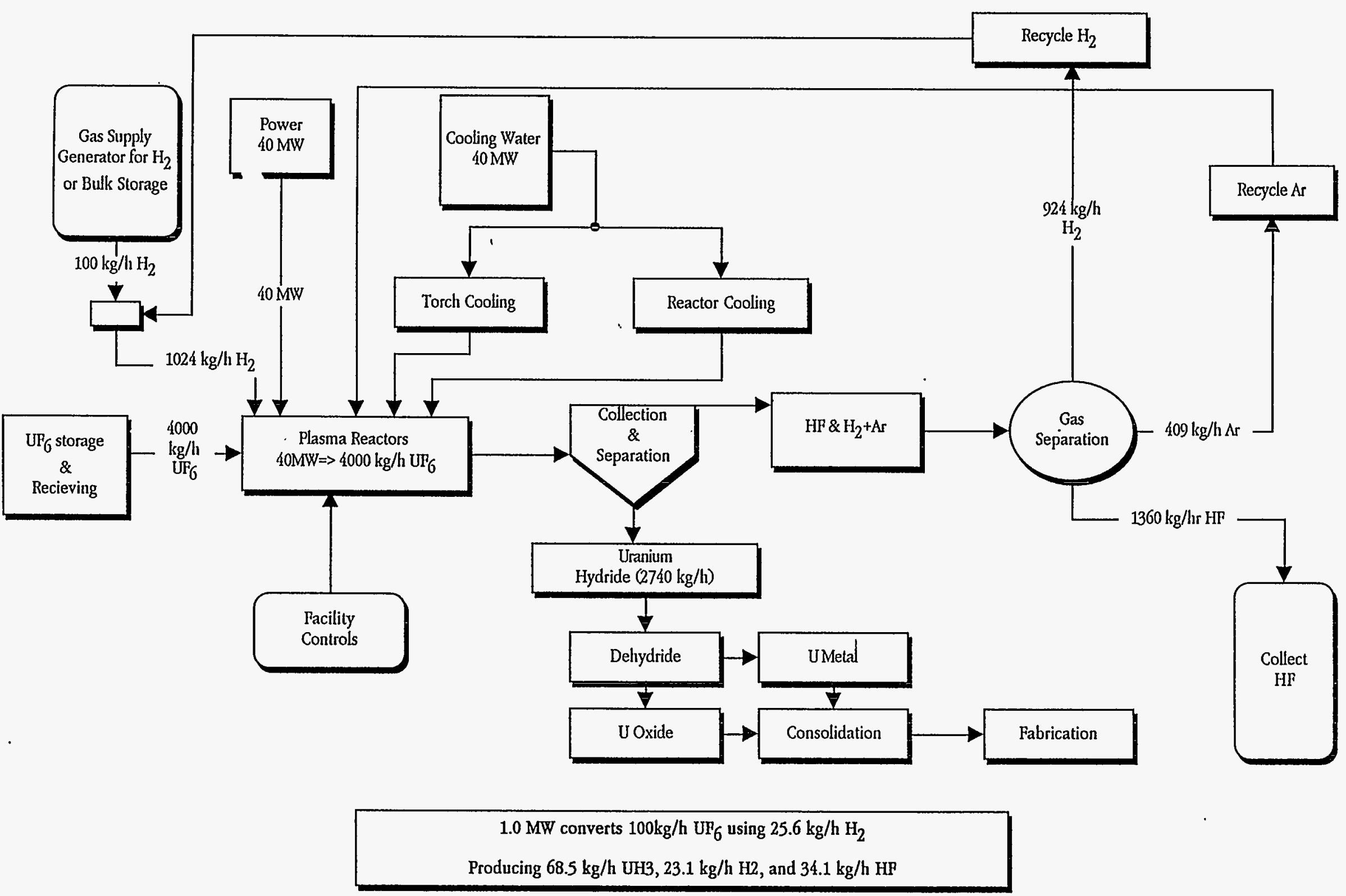

Figure 1. $\mathrm{UF}_{6}$ plant flowsheet, plasma quench reduction of $\mathrm{UF}_{6}$ by $\mathrm{H}_{2}$. 


\section{Gas separation}

5. Uranium metal melting

6. Uranium metal cutting and storage

7. Water. cooling system

8. Supply hydrogen

9. Electrical distribution and motor control center (MCC)

10. Radiation monitoring

11. Utilities and mechanical

12. Administration and central control

13. Heating, ventilation, and air conditioning (HVAC)

14. Civil construction work

15. Maintenance.

Costs identified with the 15 unit operations were summarized, and total costs were developed using a bottoms-up estimating approach. The estimate uses costs from existing DOE projects, vendor quotes, and engineering experience to develop costs for equipment, structures, utilities, materials, maintenance, and labor for each unit operation. This information generates the following:

- Studies and bench-scale test costs

- Demonstration costs

- Production facility construction costs

- Operations budget-funded activities

- Operating and maintenance costs

- Decontamination and decommissioning

- Rough order of magnitude (ROM) life-cycle costs (20 years of operation). 


\subsection{Study Team}

The overall project was initiated and directed by Carl Cooley of DOE, EM-50. A team of employees from the INEL and from the Engineering, Construction \& Environmental Group of Morrison Knudsen Corporation (MK) performed the engineering and analysis for the plasma reduction process.

\subsection{Key Assumptions}

The design was prepared with the following assumptions:

1. The process flowsheet, material/energy balances, and plasma torch power requirements are based on the schematic flowsheet shown in Figure 1.

2. The proposed facility will process a total of 400,000 metric tons of $U_{6}$ over a 20 -year period, at a rate of $4 \mathrm{t}$ per hour for 5,000 hours per year.

3. The facility will produce uranium metal as ingots and the by-product anhydrous HF.

4. The impurities in the system are bled off through the uranium metal and anhydrous HF streams. This does not affect product marketability.

5. The facility will be at or adjacent to the existing $U F_{6}$ storage areas to eliminate the need for offsite $\mathrm{UF}_{6}$ transport.

6. The facility will include warehouse capacity to store $50 \%$ of the annual production of uranium ingots each year.

7. The ${ }^{235} \mathrm{U}$ content of the depleted $\mathrm{UF}_{6}$ is $0.2 \%$. The $\mathrm{UF}_{6}$ cylinders have been in storage for 50 years.

8. Radon discharge of $1 \mathrm{Ci} / \mathrm{h}$ is assumed. 


\section{SYSTEM DESCRIPTION}

The DUPRS will convert $\mathrm{UF}_{6}$ to uranium metal ingots and produce anhydrous $\mathrm{HF}$ as a by-product. The system consists of all structures, buildings, and equipment needed to process the $\mathrm{UF}_{6}$. All equipment identified in the system design is commercially available except for the plasma reactor. A process functional diagram of the DUPRS is shown in Figure 2. A conceptual facility layout and a perspective view of the facility are shown in Figures 3 and 4, respectively. Unit operations are described below.

\subsection{Storage \& Receiving}

$\mathrm{UF}_{6}$ is contained in sealed canisters at, or adjacent to, the existing production facility. Individual canisters will be moved from the inactive storage area to an enclosed staging area served by an overhead bridge crane. The canisters will be placed into indirectly heated overpacks with sealed enclosures. The cylinders will be heated to increase the temperature of the $\mathrm{UF}_{6}$ to an estimated $140^{\circ} \mathrm{F}$ to convert solid $\mathrm{UF}_{6}$ to $\mathrm{UF}_{6}$ gas. The gas will be transferred by a vacuum pump and injected into the plasma torch reactor. The empty cylinders will be removed by the crane and taken to a storage area.

\subsection{Plasma Reactor}

The $\mathrm{UF}_{6}$ will be injected into the four parallel plasma torch reactors, each processing 1 metric ton. The plasma torch reactors consist of a plasma torch and a reactor section. Argon gas is introduced to the plasma torch, which produces a high temperature (more than $10,000 \mathrm{~K}$ ) plasma. A mixture of $\mathrm{UF}_{6}$ and $\mathrm{H}_{2}$ is introduced in the reactor section, downstream of the plasma torch. The reaction $\mathrm{UF}_{6}+3 \mathrm{H}_{2}-\rightarrow \mathrm{U}+6 \mathrm{HF}$ proceeds in the reactor section. Because the net change in the number of moles is positive, the addition of inert gases in the reactor increases the yield by decreasing the partial pressure of products. The gas mixture exits the reactor zone and is quenched to prevent the recombination of uranium and fluorine. The plasma torch and reactor sections will be cooled with water, which is recirculated through a cooling tower.

\subsection{Metal/Gas Cooling and Separation}

The mixture of gases and submicron uranium metal powder will exit the reactor and diffuser section at an estimated temperature of $1,000^{\circ} \mathrm{F}$ and an estimated pressure of 10 psia. The product stream will be cooled to $250^{\circ} \mathrm{F}$ using indirect water/gas coolers combined with static solids separation in the bottom of the coolers. Final polishing of the gas stream for the removal of uranium metal will be accomplished by electrostatic precipitation. The metal/gas separation will remove more than $99.5 \%$ of the uranium metal. The design of the conventional precipitator will be modified by a conical bottom containing an air lock, live bottom bin, and screw feeders for positive uranium metal feed to the conveying system. The gas inlet to the precipitator will be through an inlet nozzle located on the side above the conical bottom. Gas discharge will be from the top. 


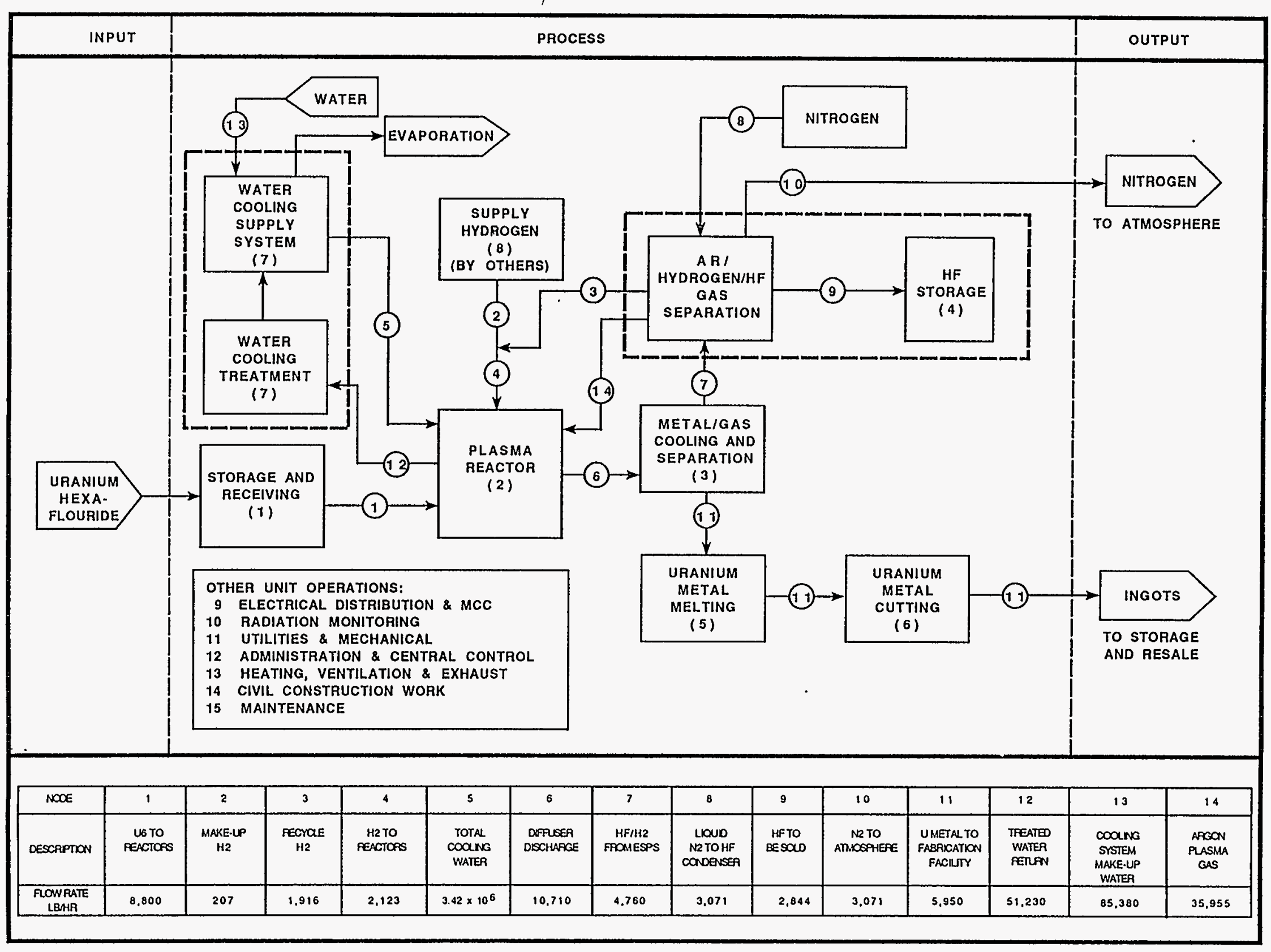

Figure 2. Process functional diagram of the DUPRS. 


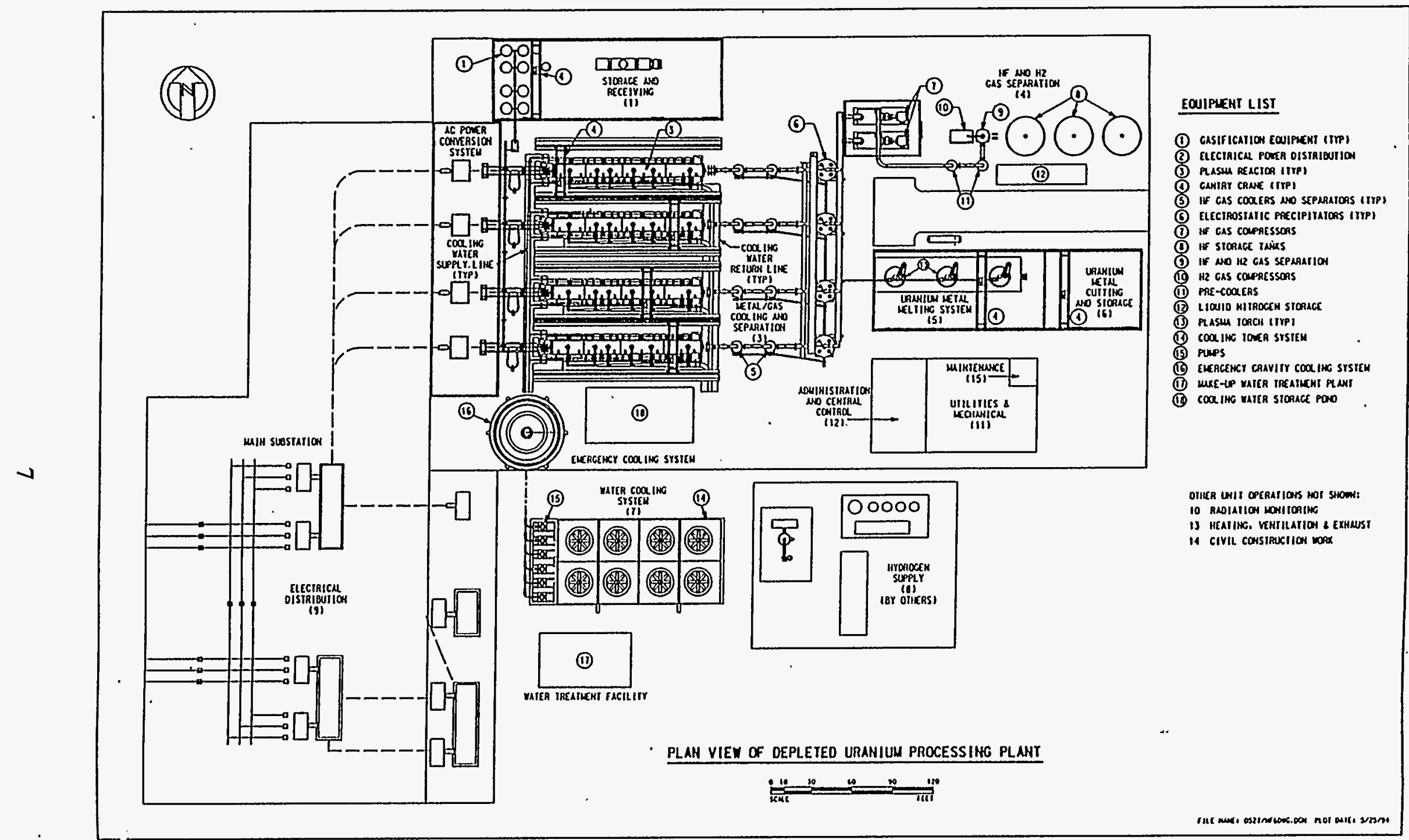

Figure 3. Conceptual layout of the DUPRS. 


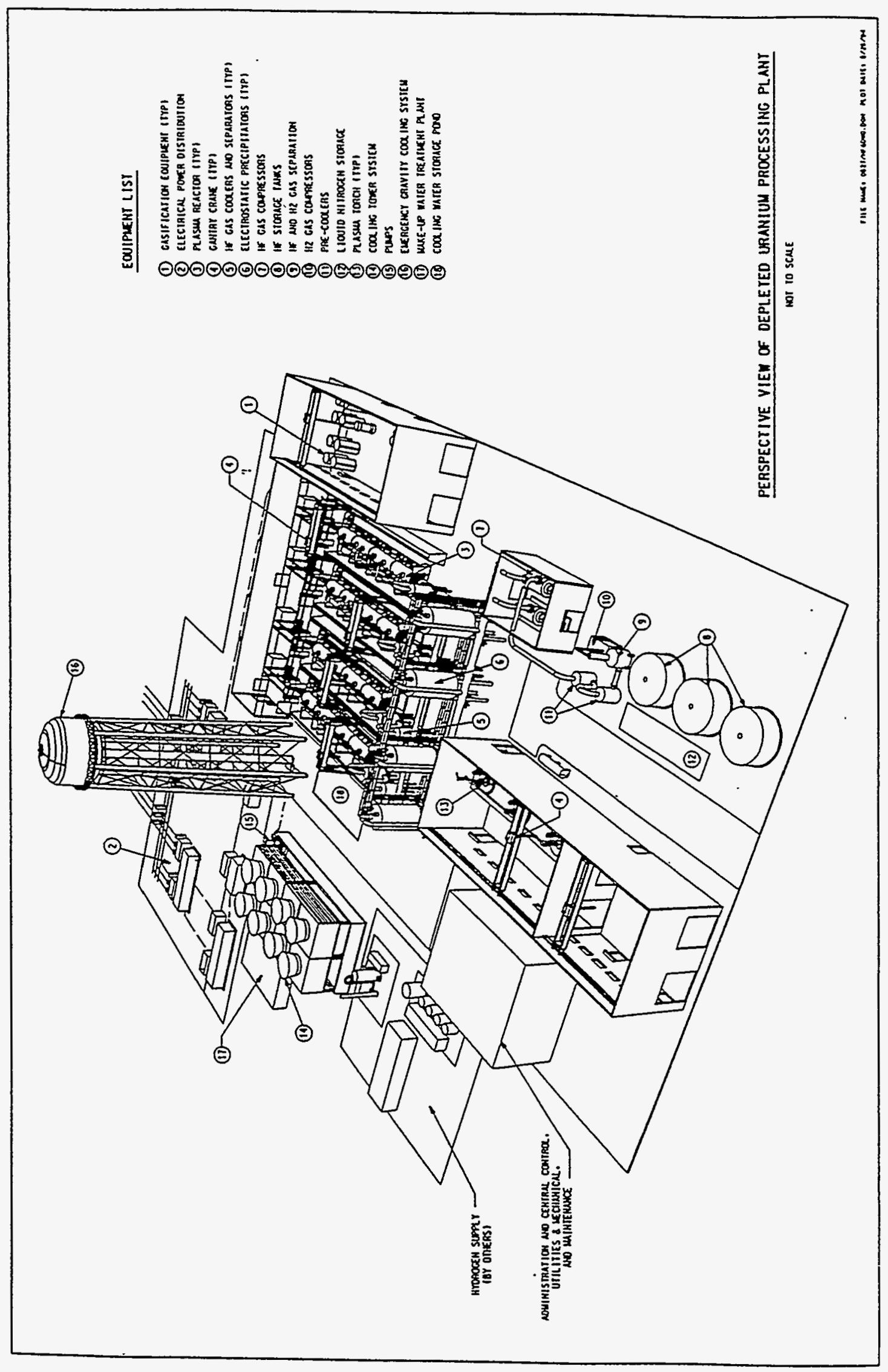

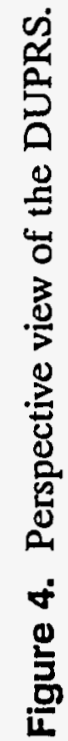




\subsection{Gas Separation}

After the solid uranium has been separated from the gas mixture, the by-product HF must be separated and removed from the system, and the remaining $\mathrm{Ar} / \mathrm{H}_{2}$ gas mixture must be separated and recycled to the plasma torch and reactor, respectively. Cryogenic condensation using liquid nitrogen will be used to separate the HF, which will be stored in tanks as a liquid. It is thought that the HF will eventually be offered for sale to industrial users. The $\mathrm{Ar} / \mathrm{H}_{2}$ gas mixture will be separated using membrane technology.

\subsection{Uranium Metal Melting}

The submicron-sized uranium metal powder separated from the gas stream will be melted in a plasma torch furnace under a helium gas atmosphere. Three melters will be required, all oriented in the upright position.

\subsection{Uranium Metal Cutting and Storage}

The melted uranium will be cast into a cooled mold. Three molds will be used to provide continuous processing rate. The ingots will be automatically cut to the required size and stored. The warehouse will be sized to store $50 \%$ of the annual production of ingots.

\subsection{Water Cooling System}

The plasma torch, reactor, and diffuser sections will be cooled by water circulating through a closed-loop cooling tower system. The system will be equipped with induced draft cooling tower fans and supported by a filtration and water treatment system. Approximately $1.5 \%$ of the circulation flow will be removed as blowdown, treated through a reverse osmosis unit, and returned to the cooling system. An additional $2.5 \%$ of the circulation flow will be makeup water required as a result of evaporation and reverse osmosis losses. An emergency gravity flow cooling system will back up the main system and will consist of an elevated 250,000 gal tank connected to the central system.

\subsection{Hydrogen Gas Supply}

The facility for the production of the gaseous hydrogen will be designed, installed, owned, operated, and maintained by an independent contractor. The cost of the facility will be covered by the price paid for the gas.

The hydrogen gas production facility will consist of a single train steam-methane reformer, a shift unit, and hydrogen purification unit. The steam-methane reformer generates carbon monoxide and hydrogen, the shift unit increases the hydrogen conversion by converting carbon monoxide and steam to carbon dioxide and hydrogen. The hydrogen purification unit will yield high-purity hydrogen by removing carbon oxides and methane in a pressure swing adsorption unit. The facility will be capable of producing 42,000 standard cubic feet (SCF) per hour of gaseous hydrogen. A by-product steam supply will also be available for export. 


\subsection{Electrical \& Motor Control Center}

Electrical power will be provided to the facility via two independent $138 \mathrm{kV}$ transmission lines, each of which will be capable of supplying the required 100-MW load. The transmission lines will terminate at the facility's main substation. The $138 \mathrm{kV}$ utility primary power voltage will be converted to $13.8 \mathrm{kV}$ secondary voltage for distribution throughout the site by two $50 \mathrm{MV} \cdot \mathrm{A}$ transformer banks. One transformer bank will supply the alternating current (AC) loads and the other the direct current (DC) loads. The main substation will consist of outdoor structures, insulators, busbars, power circuit breakers, isolator switches, resistors, and outdoor type switchgear and protective relays.

Underground feeders will carry the $13.8 \mathrm{kV}$ secondary voltage to substations located near the loads being served. AC substations capable of converting the $13.8 \mathrm{kV}$ secondary voltage to $4.16 \mathrm{kV}$ and $480 \mathrm{~V}$ will be provided for the main processing area, the water cooling system area, the liquid hydrogen plant, and the maintenance/office complex. Substations capable of converting the $13.8 \mathrm{kV}$ secondary voltage to $5 \mathrm{kV} \mathrm{DC}$ will be provided for the plasma torches and the smelters, and equipment capable of converting $480 \mathrm{~V}$ to $50 \mathrm{kV} \mathrm{DC}$ will be provided for the electrostatic precipitators (ESP).

The AC substations will consist of outdoor disconnect switches, distribution transformers, grounding resistors, and outdoor type switchgear. The DC substations will consist of outdoor disconnect switches, transformer/rectifier sets, power factor and harmonic filter cabinets, and rectifier cooling systems.

\subsection{Radiation Monitoring}

Redundant environmental monitoring will be required to analyze work areas and the environment for radon, HF, hydrogen, argon, and suspended particulates.

\subsection{Utilities and Mechanical}

Utilities and mechanical systems include service water, closed-circuit cooling tower water, compressed air, service instrument air, and auxiliary systems.

\subsection{Administration and Central Control}

Facilities will he provided for onsite administrative personnel. See Table 1 for a breakdown of required personnel. Space will also be provided to house the central control room.

\subsection{HVAC}

All enclosed areas will have ventilation systems designed to standards for radon control. HVAC costs have been included in the building costs. 
Table 1. Estimated facility administrative staff (day shift only unless otherwise noted).

$$
\text { Job }
$$

FTE workers

Security (4 shifts)

4

Plant manager

1

Shift superintendent ( 3 shifts)

3

Maintenance superintendent

1

Procurement/accounting manager

1

Environmental, safety, and health

6

manager and staff ( 3 shifts)

Personnel manager

Support

3

Environmental engineer

2

Secretary/clerk

3

Total

\subsection{Civil Construction Work}

The DUPRS plant will be surrounded by an 8-ft high chain-link fence. In addition, yard piping, sanitary sewers, and stormwater sewers will be provided. The plant will have a network of paved roadways for maintenance vehicles to access key pieces of equipment.

\subsection{Maintenance}

An enclosed building will be provided for maintenance personnel. It will be sized to accommodate the equipment requiring routine maintenance. 


\section{MASS FLOW RATES}

This section contains a summary of the mass flow rates of the major input and output of the DUPRS. Detailed information on mass flow rates is presented in the process functional diagram in Figure 2.

\subsection{Flow Rates}

For the purpose of this study, the feed rates are calculated based on the assumption that the facility will operate for 20 years and process 4 metric tons of $U_{6}$ per hour (see Table 2). A total of 400,000 metric tons will be processed (see Figure 5).

Table 2. Amounts to be processed in the various DUPRS areas.

\begin{tabular}{|c|c|}
\hline DUPRS areas & $\mathrm{lb} / \mathrm{h}$ \\
\hline $\mathrm{UF}_{6}$ to reactors & 8,800 \\
\hline Makeup $\mathrm{H}_{2}$ & 207 (619 SCFM) \\
\hline Recycle $\mathrm{H}_{2}$ & $1,916(5,732$ SCFM $)$ \\
\hline Recycle Ar & 35,955 (5,385 SCFM, 36:1 Ar/UF 6 molar ratio) \\
\hline $\mathrm{H}_{2}$ to reactors & $2,123(6,351 \mathrm{SCFM})$ \\
\hline Total cooling water & $3.415 \times 10^{6}$ \\
\hline Diffuser discharge & 10,710 \\
\hline $\mathrm{HF} / \mathrm{H}_{2} / \mathrm{Ar}$ from ESPs & $4,760(11,875$ SCFM $)$ \\
\hline Liquid $\mathrm{N}_{2}$ to $\mathrm{HF}$ condenser & 3,071 (656 SCFM) \\
\hline HF (to be sold) & 2,844 \\
\hline $\mathrm{N}_{2}$ (to atmosphere) & $3,071(656 \mathrm{SCFM})$ \\
\hline Uranium metal & 5,950 \\
\hline Treated water return & 51,230 \\
\hline Cooling system makeup wat ${ }^{-} ;$ & 85,380 \\
\hline
\end{tabular}

\subsection{Reusable Product}

The hydrogen production facility will generate a by-product steam supply that will be available for export. The uranium metal and the HF will be sold for reuse. 


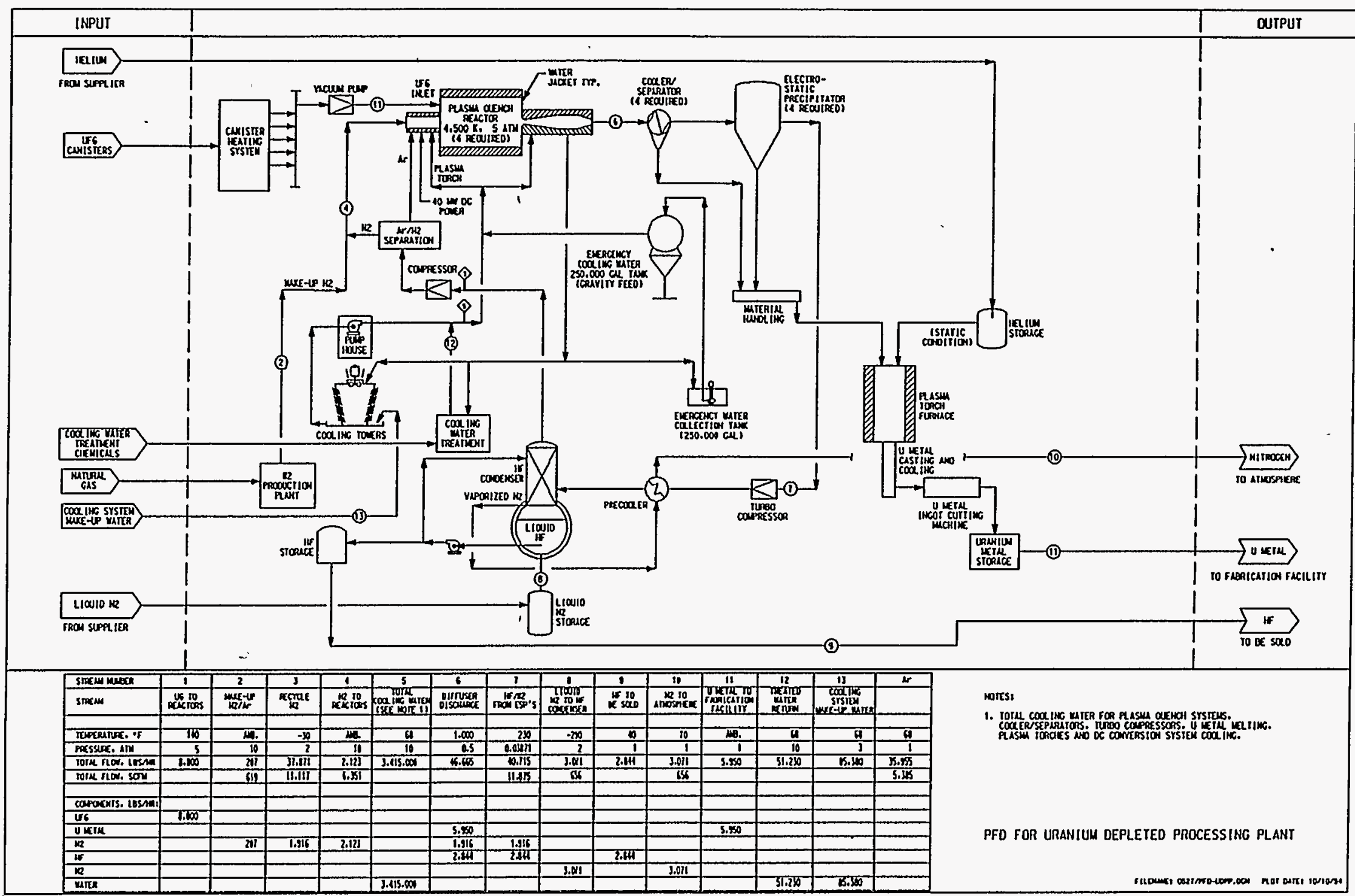

Figure 5. Mass flow balance for the DUPRS. 


\subsection{System Waste}

The air treatment facilities for the DUPRS will generate secondary waste. The nature and quantity of these secondary wastes have not been determined. $\mathrm{NO}_{2}$ will be discharged to the atmosphere or treated and released as nitrogen. Cooling water will be a closed system and will not be discharged, except that portion which will be discharged from the reverse osmosis unit. The uranium metal and the HF will be sold for reuse.

Other secondary waste will consist of housekeeping trash, disposable garments, equipment maintenance waste, spent baghouse, ventilation and high-efficiency particulate air filter elements, accumulations in equipment drains and floor drains, machinery oil, and decontamination waste.

\subsection{Key Assumptions for Mass Flow Calculations}

The key assumptions for the mass flow calculations are:

- The uranium contains $0.2 \%{ }^{235} \mathrm{U}$

- The DUPRS will be located near the stored $\mathrm{UF}_{6}$. 


\section{LIFE-CYCLE COST ESTIMATE}

This section contains a summary of the project life-cycle cost (PLCC) estimate for the DUPRS. The PLCC estimate includes treatment costs for processing $\mathrm{UF}_{6}$. The cost of transporting $\mathrm{UF}_{6}$ to the processing facility has not been included. The facility has been sized to treat $400,000 \mathrm{t}$ of $\mathrm{UF}_{6}$ over a 20 -year operating life. The total operating time during the facility life cycle is 100,000 hours.

\subsection{Estimating Methods, Basis, and Assumptions}

The following assumptions were used to derive the life-cycle cost estimate:

1. Generation of hydrogen will be accomplished by a lessee. The lessee will absorb all capital and operating costs and will be included in the cost of the hydrogen supplied.

2. Building costs include materials to construct pre-engineered buildings, concrete slabs, excavation, backfill, and site work. Where only concrete slabs are to be constructed, their costs, including excavation, backfill, and site work, are included as a building cost in the appropriate unit operation. The building costs also include HVAC, crane support structures (where appropriate), and electrical installation.

3. Pre-engineered buildings will house the following unit operations:

- Administration and central control

- $\quad$ Storage and receiving

- Plasma reactor

- Uranium-metal melting

- Uranium metal cutting and storage

- Maintenance.

The unit operations that will be built on open-air concrete pads are:

- Metal/gas cooling and separation

- $\quad \mathrm{HF}$ and $\mathrm{H}_{2}$ gas separation

- Water cooling system.

4. Raw material usages and costs will be as shown in Table 3 . 
Table 3. Raw material usages and costs.

\begin{tabular}{lll}
\hline \multicolumn{1}{c}{ Item } & \multicolumn{1}{c}{ Annual quantity } & \multicolumn{1}{c}{ Cost } \\
\hline $\mathrm{UF}_{6}$ & $44,000,000 \mathrm{lb}$ & None \\
Hydrogen & $196,500,000 \mathrm{SCF}$ & $\$ 3.70 / 1,000 \mathrm{SCF}$ \\
Nitrogen & $360,000,000 \mathrm{SCF}$ & $\$ 2.80 / 1,000 \mathrm{SCF}$ \\
Ar/H ${ }_{2}$ separation & $1,710,000,000 \mathrm{SCF}$ & $\$ 1.00 / 1,000 \mathrm{SCF}$ Ar separated \\
Electrical energy & $250,000 \mathrm{MW} \cdot \mathrm{h}$ & $\$ 0.03 / \mathrm{kW} \cdot \mathbf{h}$ \\
Helium & Negligible & - \\
\hline
\end{tabular}

5. The HVAC system will be maintained by maintenance personnel. Maintenance personnel costs are absorbed in the maintenance unit operation.

6. Administrative personnel are allotted $\$ 7,000$ for computers, desks, etc.

7. The allowance for piping/mechanical includes structural supports for platforms, piping, and walkways and minor pump and piping systems.

8. The allowance for electrical/controls includes all additional instrumentation required to ensure safe operation of the unit operations and their interaction with other unit operations.

9. The allowance for calibration/testing/startup includes calibrating gauges and instruments to ensure compatibility with the process requirements. The allowance also includes startup costs associated with vendor-supplied equipment and the integration of the equipment into the treatment system.

10. The electrical utility cost is spread proportionally across the unit operations.

11. Makeup water used in the water cooling system unit operation is assumed to cost $\$ 17 / 1,000 \mathrm{SCF}$.

12. Cutting of the uranium ingots will be performed within an argon atmosphere.

Figure 6 shows the steps used in the cost estimating approach.

Cost information in this report was obtained during the second quarter of FY 1994. The information is based on the currently available knowledge about waste processing requirements, technology availability, and cost data. The information may require updating when additional knowledge is gained in these areas. All facilities except the hydrogen production plant are assumed to be government owned and contractor operated. 


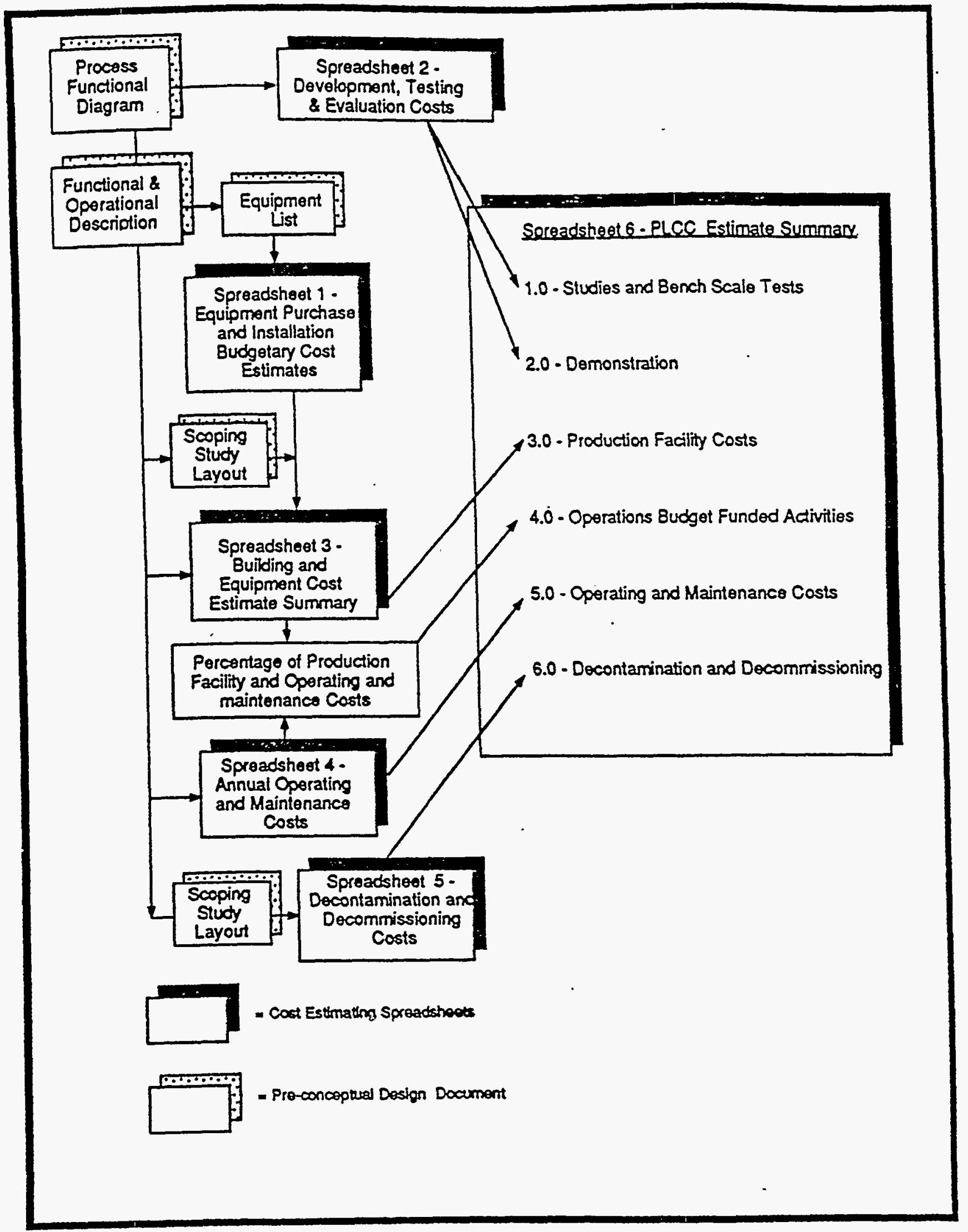

Figure 6. Diagram of cost estimating approach. 


\subsection{Treatment Facility PLCC Estimate Summaries}

The PLCC estimate is divided into six components (see Figure 6). Each was estimated separately. A summary of the PLCC estimate is presented in Table 4. Detailed cost breakdown spreadsheets are presented in Appendix A. Discussions of the cost components are presented below.

\subsubsection{Studies and Bench-Scale Tests and Demonstration Tests}

Bench-scale studies were undertaken at the INEL to demonstrate the feasibility of the process. These experiments successfully demonstrated that a plasma torch could be used to reduce $\mathrm{UF}_{6}$ to $U$ and HF. Small quantities of metallic uranium were produced, and the rapid quench of the product stream was also demonstrated. No back-reaction of the products to $\mathrm{UF}_{\mathrm{x}}$ compounds was detected.

Demonstration and scaling will proceed through three phases: (a) laboratory development, (b) pilot-scale testing, and (c) production-scale testing. Laboratory development will consist of large bench-scale testing, pilot-scale increases throughput to the $100-200 \mathrm{~kg} / \mathrm{h}$ rate and includes the complete plant. Production-scale addresses issues associated with the scaling of specific pieces of hardware, such as plasma devices or particle collection systems. Total research and development costs are estimated at about $5 \%$ of total life-cycle costs.

4.2.1.1 Laboratory Development. Sufficient experimental data were acquired during successful bench-scale demonstration, and the theoretical understanding of the thermal plasma reduction of $\mathrm{UF}_{6}$ has progressed to the point that a large bench-scale demonstration reactor can be designed. However, the performance of each component must be evaluated. The major attributes of this reactor are an increase in volume-to-surface ratio by a minimum of a factor of 10 and the development of a high-efficiency $(>60 \%)$ multiple source plasma with co-axial $\mathrm{UF}_{6}$ injection. Throughput of $\mathrm{UF}_{6}$ is expected to be on the order of $1 \mathrm{~kg} / \mathrm{h}$. Detailed process diagnostics and a detailed material balance will be performed. Component designs will be experimentally evaluated and performance characteristics verified coincident with the development of the pilot-scale reactor design.

4.2.1.2 Pilot Scale. The pilot-scale demonstration increases throughput of $\mathrm{UF}_{6}$ to the $100-200$ $\mathrm{kg} / \mathrm{h}$ range. At this scale, the performance of all major components can be addressed, and realistic data on plasma device operating lifetimes, system efficiencies, etc., can be evaluated and problem areas can be identified. Pilot scale is an important step for a process that is significantly different from other conventional chemical processes.

4.2.1.3 Production-Scale Testing. It is anticipated that the performance of some components, which are identified $\mathrm{du} \because$, pilot-scale testing, will need to be further evaluated and modified. An example may be the scaling of plasma devices and reactors to the multimegawatt level. Additional design, testing, and evaluation will be performed in parallel with the development of the plant design and construction. 
Table 4. ROM life-cycle cost estimate summary for the DUPRS.

Cost

Cost component

Cost items

$(\$ \times 1000)$

1.0 Studies and bench-scale test and demonstration costs

Subtotal 1.0

$(5 \%$ of 6.0$)$

$\$ 55,948$

2.0 Production facility construction costs

2.1 Design cost

2.2 Inspection cost

(18\% of 2.4$)$

$\$ 26,079$

(7\% of 2.4$)$

$\$ 10,142$

2.3 Project management

(10\% of 2.4$)$

$\$ 14,488$

2.4 Construction cost

2.4.1 Building structure costs

$\$ 3,464$

2.4.2 Equipment costs

2.4.3 Indirect

(29\% of 2.4 .1 and 2.4 .2 )

$\$ 108,849$

Subtotal 2.4

2.5 Construction management

(17.1\% of 2.4$)$

$\$ 32,571$

$\$ 144,884$

( $10 \%$ of 2.4 )

$\$ 24,775$

$\$ 14,488$

2.7 Contingency

(25\% of 2.1 through 2.5 )

$\$ 55,092$

$\$ 289,948$

3.0 Operations budget-funded activities

3.1 Conceptual design

3.2 Safety assurance

3.3 National Environmental Policy Act (NEPA) permitting

(1.5\% of 2.0$)$

$\$ 4,349$

(1\% of 2.0$)$

$\$ 2,899$

(\$6 million for environmental impact

$\$ 7,000$

statement, \$1 million for environmental assessment)

3.4 Preparation for operations

$(100 \%$ of 4.0$)$

$\$ 37,664$

(10\% of 3.1 through 3.4 )

$\$ 5,191$

Subtotal 3.0

$(1.0,2.0$, and 3.0$)$

$\$ 402,999$

Total Initial Cost

-

(25\% of 4.1 through 4.4 )

$\$ 7,533$

4.5 Contingency

(20 times Subtotal 4.0)

$\$ 37,664$

4.7 Total 20-year O\&M cost

$\$ 753,280$

5.0 Decontamination and decommissioning

$\$ 18,622$

6.0 ROM life-cycle costs

(20 years operation)

$\$ 1,174,901$ 


\subsubsection{Facility Capital Costs}

The third cost component, production facility construction costs (also referred to as facility capital cost or "line-item" cost), consists of five key subcomponents:

4.2.2.1 Design. The design subcomponent includes Title 1, or preliminary design, and Title 2, or detailed design. Design is estimated at $25 \%$ of facility construction cost for an alpha facility.

4.2.2.2 Inspection. The inspection subcomponent includes Title 3, or engineering support, during construction. Inspection is estimated at $7 \%$ of the facility construction cost.

4.2.2.3 Project Management. The project management subcomponents include project management costs incurred by both $\mathrm{DOE}$ and the site management and operations contractor. Project management is estimated at $10 \%$ of facility construction cost.

4.2.2.4 Construction Cost. Facility construction cost estimates are developed from a preconceptual design package. The preconceptual design packages include a process functional diagram with mass flow rates, a facility layout, and a summary of functional and operational requirements. Construction is divided into the following three parts:

4.2.2.4.1 Building and Structures-Building and structure costs are estimated by multiplying building unit costs by the space required by each unit operation. Assumed unit rates are applied to several categories of buildings: $\$ 180 / \mathrm{ft}^{2}$ for the administration and central control building, $\$ 225 / \mathrm{ft}^{2}$ for all other enclosed buildings, and $\$ 45 / \mathrm{ft}^{2}$ for cast-in-place concrete slabs. Building unit rates include all material and labor needed for constructing the building shell, including utilities, lighting, HVAC, and site development costs. Site development costs include all excavation and backfill activities and assume that all utilities (power, sanitary and storm sewers, site communication and alarms) and access roads are available within $100 \mathrm{ft}$ from the outer walls of the treatment facility. Special steel supports, foundations, and ventilation ducts and hoods required by the process components are not included in the standard building unit rates. These rates include costs for imposing stringent DOE health and safety standards on facility construction.

4.2.2.4.2 Equipment-Cost estimates for major equipment were obtained by soliciting budgetary costs from suppliers or by making engineering judgments. Cost for equipment installation is estimated to be an additional $20 \%$ of the equipment capital cost. Allowances for electrical, instrumentation, and mechanical bulks are estimated as a percentage of the total equipment purchase and installation costs. Details are documented in Appendix A.

4.2.2.4.3 Indirect Costs-Indirect costs include subcontractor overhead and fee. This is estimated at $29 \%$ of the total of building, structure, and equipment costs.

4.2.2.5 Construction Management. The construction management subcomponent is estimated at $17 \%$ of construction costs, which is the sum of the equipment, building, and indirect costs.

Construction management includes material and services procurement and control activities, which are usually handled by the site construction management contractor. 
Allowance for project scope change or management reserve is estimated at $10 \%$ of construction costs.

Because the costs are a planning-level estimate, a $25 \%$ contingency is included. The contingency is applied to the total of all components in the production facility construction cost.

\subsubsection{Preconstruction and Preoperational Activities}

The fourth cost component (operations budget-funded activities) includes conceptual design, safety assurance, National Environmental Policy Act (NEPA) compliance efforts and permitting, preparation for operation, and project management costs. Conceptual design is estimated to be $1.5 \%$ of the total production facility construction cost; the cost for safety assurance (safety analysis reports) is estimated at $1 \%$ of the total production facility construction cost. The costs for an environmental impact statement for NEPA compliance and for the Resource Conservation and Recovery Act, Toxic Substances Control Act, Clean Air Act, and state, local, and other permits are estimated at \$6 million. The cost for an environmental assessment is estimated at $\$ 1$ million. All other subcomponents of the cost of the operations budget-funded activities, including preoperation readiness reviews, facility startup, operator hiring, and training costs, are assumed to be equal to 1 year of total facility operating costs.

\subsubsection{Operating Cost}

The fifth cost component (operation and maintenance [O\&M]) consists of five subcomponents: operating labor, utilities, consumable materials, maintenance parts and equipment, and maintenance labor costs. The first three subcomponents are estimated by analyzing the requirements of the facility (see Tables 1 and 5 for personnel requirements for administration and operations, respectively). The remaining two subcomponents are estimated as a percentage of the original equipment installed at the facility. Accordingly, the costs for annual maintenance spare parts and replacement equipment are estimated to be $7 \%$ of the original equipment purchase cost. Maintenance labor is estimated to cost $250 \%$ of the cost of spare parts and replacement on an anual basis.

\subsubsection{Decontamination and Decommissioning}

The sixth cost component, decontamination and decommissioning (D\&D), is estimated by multiplying a $D \& D$ unit rate of $\$ 450$ per square foot of area cleaned by the square footage of the total facility (Schlueter 1992). 
Table 5. Estimated facility operation staff.

\begin{tabular}{|c|c|}
\hline Unit operation & $\begin{array}{c}\text { Total } \\
\text { FTE workers }\end{array}$ \\
\hline Storage and receiving & 10 \\
\hline Plasma reactor & 8 \\
\hline Metal/gas cooling and separation & 4 \\
\hline $\mathrm{HF}$ and $\mathrm{H}_{2}$ gas separation & 2 \\
\hline Uranium metal melting & 4 \\
\hline Uranium metal cutting & 4 \\
\hline Water cooling system & 4 \\
\hline Supply hydrogen & 0 \\
\hline Electrical dist. and MCC & - 4 \\
\hline Radiation monitoring & 2 \\
\hline Utilities and mechanical & 2 \\
\hline Total & 44 \\
\hline
\end{tabular}




\section{SYSTEM EVALUATION}

The goal of evaluating the system is to qualitatively assess technology risks, including system maturity and development work needed to make the system ready for detailed design. Key issues related to system compliance are identified and discussed.

Below is a listing of issues and uncertainties observed during the preconceptual design.

- $\quad$ Plasma quench technology has only been demonstrated at a small bench scale. Considerably more research and development is required to verify process kinetics and scalability.

- Bench-scale and pilot-plant testing would be required before any final design could be started. Although all of the equipment identified in this feasibility study except for the plasma reactors is used in industry, it has not been used for this purpose nor in this combination.

- The process will contain gaseous hydrogen at high temperature. A leak has the potential to cause an explosion. This risk is comparable to many chemical process industries and must be managed carefully in design.

- Fire prevention and protection must be a critical element of the design, because uranium dust is pyrophoric and there exists a potential for hydrogen gas releases. Therefore, process controls, safety interlocks and detection systems will be necessary components of the process.

- Control and treatment of radon will be necessary for worker, public, and environmental protection.

- $\quad \mathrm{HF}$ is extremely toxic and dangerous to handle. Although there are industrial procedures for handling $\mathrm{HF}$, the combination of high-temperature, positive and negative pressures, and ignitable materials make safety designs a crucial part of any process design.

- The $\mathrm{UF}_{6}$ canisters would be returned to their original storage area. No provisions have been made for their decontaminating, decommissioning, or recycling. 


\section{CONCLUSION}

DOE is currently storing approximately 576,000 metric ton of depleted $\mathrm{UF}_{6}$. Treatment methods must be developed to convert this $\mathrm{UF}_{6}$ to a stable form. One method being considered is to use a plasma-based process to reduce the $\mathrm{UF}_{6}$ to uranium metal. This process has the potential advantage of recycling all of the feed (as uranium metal and anhydrous HF) instead of merely treating and disposing of the waste.

This investigation has demonstrated the feasibility of using the plasma-based process. Successful results of bench-scale experiments suggest that the process is sufficiently well understood to proceed to laboratory and pilotscale.

A conceptual design of a production-scale facility was developed to provide estimates for the life-cycle costs. The use of certain assumptions was necessary to estimate the life-cycle costs. However, all of the equipment to be used has already been proven industrially, albeit not in this application. The total cost of processing $400,000 \mathrm{t}$ of $\mathrm{UF}_{6}$ is estimated to be approximately $\$ 1.2$ billion, or approximately $\$ 3.00$ per $\mathrm{kg}$ of $\mathrm{UF}_{6}$ processed. This compares favorably with other proposed treatment methods. 


\section{REFERENCES}

1. Schlueter, R., et. al, Low Level and Transuranic Waste Transportation, Disposal and Facility Decommissioning Cost Sensitivity Analysis, EGG-WTD-10092, May 1992. 
Appendix A

Cost Tables 
A-2 


\section{Appendix A}

\section{Cost Tables}

Table A-1. Equipment Purchase \& Installation Budgetary Cost Estimate

Table A-2. Building and Equipment Material \& Installation Cost Estimate Summary

Table A-3. Annual Operating \& Maintenance Costs

Table A-4. Decontamination \& Decommissioning Costs

Table A-5. Factor Sheet 

Table A-1: Equipment Purchaso \& Installation Budgetary Cost Estimates Depleted Uranium (Cost Modulo DUPRS)

\begin{tabular}{|c|c|c|c|c|c|c|c|c|c|}
\hline \multicolumn{3}{|l|}{ p } & \multicolumn{7}{|c|}{ DEPLETED URANIUN: } \\
\hline & \multirow[b]{2}{*}{ DESCRIPTION } & \multirow{2}{*}{$\begin{array}{l}\text { FAC. } \\
\text { CAT. }\end{array}$} & \multirow[b]{2}{*}{$\mathbf{H P}$} & \multicolumn{3}{|c|}{ MATIS. EOUUIP } & \multicolumn{3}{|c|}{ INST, cosTs } \\
\hline & & & & QTY & $\begin{array}{l}\text { Jnit Cont } \\
\text { S1000': }\end{array}$ & $\begin{array}{l}\text { Amount } \\
\text { 110000? }\end{array}$ & $\begin{array}{c}\text { Unit Cost } \\
\text { t1000's }\end{array}$ & \begin{tabular}{|l|} 
Anount \\
$31000^{\prime}$
\end{tabular} & $\begin{array}{l}\text { Totml } \\
\text { U. }\end{array}$ \\
\hline \multirow{9}{*}{1031} & 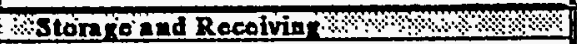 & W. & \% & mat & $3+3:-$ & Pि० & 10 & $10 \%$ & \\
\hline & - Gasification Equipment & $\mathbf{E}$ & & 8 & 60 & 480 & 12 & 96 & 576 \\
\hline & - Material Handlias Equipment & E & & 1 & 95 & 95 & 19 & 19 & 114 \\
\hline & - Vapor Collection \& Distribution Syztem & E & & 1 & $2 \pi 7$ & 277 & 5s & 55 & 332 \\
\hline & - Instrumentation & $\mathbf{E}$ & & 1 & 163 & 163 & 33 & 33 & 196 \\
\hline & - Allowance for piping/mechanial & $\mathbf{E}$ & & 1 & 42.6 & 43 & 85 & 85 & 128 \\
\hline & - Allowance for electricaVcontrob & $\underline{E}$ & & 1 & 42.6 & 43 & 85 & 85 & 128 \\
\hline & - Allowrnce for clibration/lestingheurt-up & $E$ & & 1 & 10.5 & 11 & 77.4 & 77 & 88 \\
\hline & Total Storngond Rocoiving & & & + & PM+ & 1112 & 1\%. & 450 & 1562 \\
\hline \multirow{11}{*}{ \%\$2 } & Plarimu Reación $\$$ & II\% & २ & $\%$ & 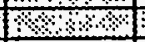 & खि। & $1 \times 3$ & 81 & $1 \%$ \\
\hline & - Plesma Torch & $\mathbf{E}$ & & 4 & 1200 & 1800 & 240 & 960 & 5760 \\
\hline & - Reactorw/converging/diversing nozles \& diffu & 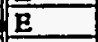 & & 4 & 3753 & 15012 & 751 & 3004 & 18016 \\
\hline & - Insirumentition/Controb (Cooline W/ater) & $E$ & & 4 & 140 & 560 & 28 & 112 & 672 \\
\hline & - Siructural Supports & $E$ & & (4) & 180 & 720 & 36 & 144 & 864 \\
\hline & - Snfety sepurntion wall & $E$ & & 5. & $\mathbf{6 0}$ & 300 & 12 & 60 & 360 \\
\hline & - Gantry Crano & $E$ & & 4 & 20 & 80 & 4 & 16 & 96 \\
\hline & - Instrumentition (Reactor) & $\underline{\mathbf{E}}$ & & 1 & 814 & 814 & 163 & 163 & 977 \\
\hline & - Allowance for piping/mechanial & $E$ & & 1 & 2147.2 & 2147 & 3007.2 & 3007 & 5154 \\
\hline & - Allowance for electrical/controls & $E$ & & 1 & 1503 & 1503 & 2148 & 2148 & 3651 \\
\hline & - Allowanco for calibration/estinghtart-up & E & & 1 & 518.7 & 519 & 4807 & 4807 & 5326 \\
\hline & Total Plarma Roactor & & $\%$ & 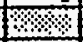 & W. & 26455 & +1? & 1421 & 10876 \\
\hline \multirow[t]{10}{*}{$8 \vee \vee 83$} & 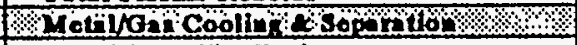 & III & 8 & \%। & $1 \%$ & $3 \%$ & భ. & W\% & 13 \\
\hline & - Material Handling Equipment & $\mathbf{E}$ & & 1 & 160 & 160 & 32 & 32 & 192 \\
\hline & - Hydrosen Flouride Gas Coolers/Separtor & $\mathbf{E}$ & & 8 & 92 & 736 & 18 & 14 & 880 \\
\hline & - Electrostatic Precipitators & $\mathbf{E}$ & & 4 & 162 & 648 & 32 & 128 & 776 \\
\hline & - Gas Compressors includies motors & $\mathbf{E}$ & & 2 & 140 & 280 & 28 & 56 & 336 \\
\hline & - Instrumentation & $\mathbf{E}$ & & 1 & 407 & 407 & 81 & 81 & 488 \\
\hline & - Allowance for pipin/mechanical & E & & 1 & 182.4 & 182 & 252 & 252 & 434 \\
\hline & - Allowance for electricalleontrob & $\mathbf{E}$ & & 1 & 127.7 & 128 & 180 & 180 & 308 \\
\hline & - Allowance for calibration/testing/ztart -up & $E$ & & 1 & 50.8 & 51 & 436.5 & 437 & 488 \\
\hline & Total Molevar Coolies \& Soperntion & & & +1 & 16. & 2592 & $\%$ & 1310 & 3902 \\
\hline \multirow{13}{*}{\begin{tabular}{|l|}
64 \\
\\
\\
\\
\\
\\
\\
\\
\end{tabular}} & 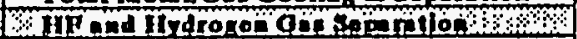 & II:W & $\$$ & (1) & ; & 21 & 4 & $0 \%$ & क. \\
\hline & - OAs Compresion Includler molors & $\mathbf{E}$ & & 2 & 140 & 280 & 28 & 56 & $\mathbf{3 3 6}$ \\
\hline & - HF \& Hydrogen Gas Sepantion & $\mathbf{E}$ & & 2 & 210 & 420 & 42 & 84 & 504 \\
\hline & - Pra-Cooler & E & & 4 & 55 & 220 & 11 & 4 & 264 \\
\hline & - Liquld Nitrogen Stongo & $\underline{E}$ & & 4 & 80 & 240 & 12 & 48 & 288 \\
\hline & - Pumpe & $\underline{\mathbf{E}}$ & & 4 & 3 & 12 & 1 & 1 & 16 \\
\hline & - Hydrogen Fluoride Stonge Tank & $\mathbf{E}$ & & 3 & 48 & 144 & 10 & 30 & 174 \\
\hline & - Additiomal pipin/mechanicalallow not incl bel & $\underline{E}$ & & 1 & 35 & 35 & 7 & 7 & 42 \\
\hline & - Instrumentution & $E$ & & i & 305 & 305 & 61 & 61 & 366 \\
\hline & - Allowance for piping/mechanial & $\underline{E}$ & & 1 & 135.1 & 135 & 191.1 & 191 & 326 \\
\hline & - Allowance for electrical/controls & $\bar{E}$ & & 1 & 94.6 & 95 & 136.5 & 137 & 232 \\
\hline & - Allowance for calibration/testing/stert - up & $\underline{E}$ & & 1 & 37.7 & 38 & 331 & 331 & 369 \\
\hline & Total HP and Hydroson Oas Sopention & & है: & ? & +1. & 1924 & ए। & 993 & 2917 \\
\hline \multirow{6}{*}{\begin{tabular}{|l|}
+15 \\
\\
\\
\\
\end{tabular}} & 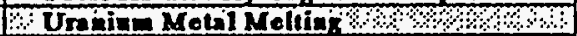 & IT: & है & ओ & m & का & का & मा & 20 \\
\hline & - Phima torch metal mell. sys. (inch ins /eonirols) & $\mathbf{E}$ & & 3 & 5000 & 15000 & 1000 & 3000 & 18000 \\
\hline & - Cnno & $E$ & & 1 & 25 & 25 & 5 & 5 & 30 \\
\hline & - Allowance for piping/mechanial & $\underline{E}$ & & 1 & 1502.5 & 1503 & 2103.5 & 2104 & 3607 \\
\hline & - Allowance for electrical/conirols & E & & 1 & 1051.8 & 1052 & 1502.5 & 1503 & 2555 \\
\hline & - Allowance for calibration/hesting/alart - up & $\mathrm{E}$ & & 1 & 351.6 & 352 & 3306 & 3306 & 3658 \\
\hline
\end{tabular}




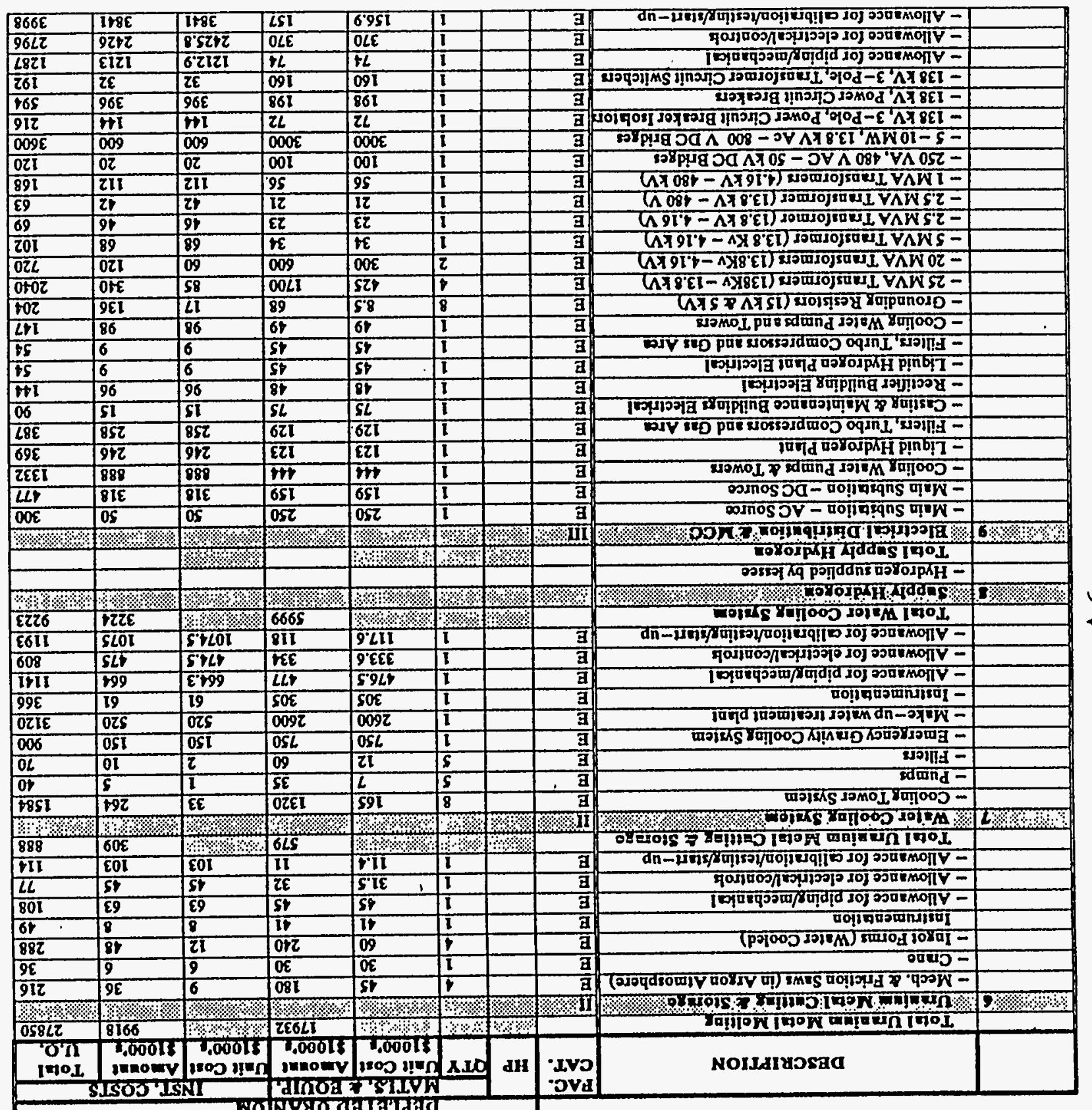

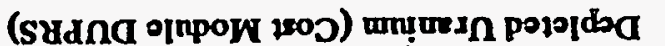

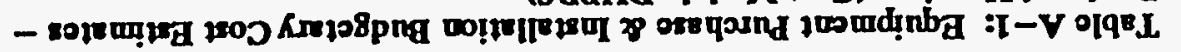




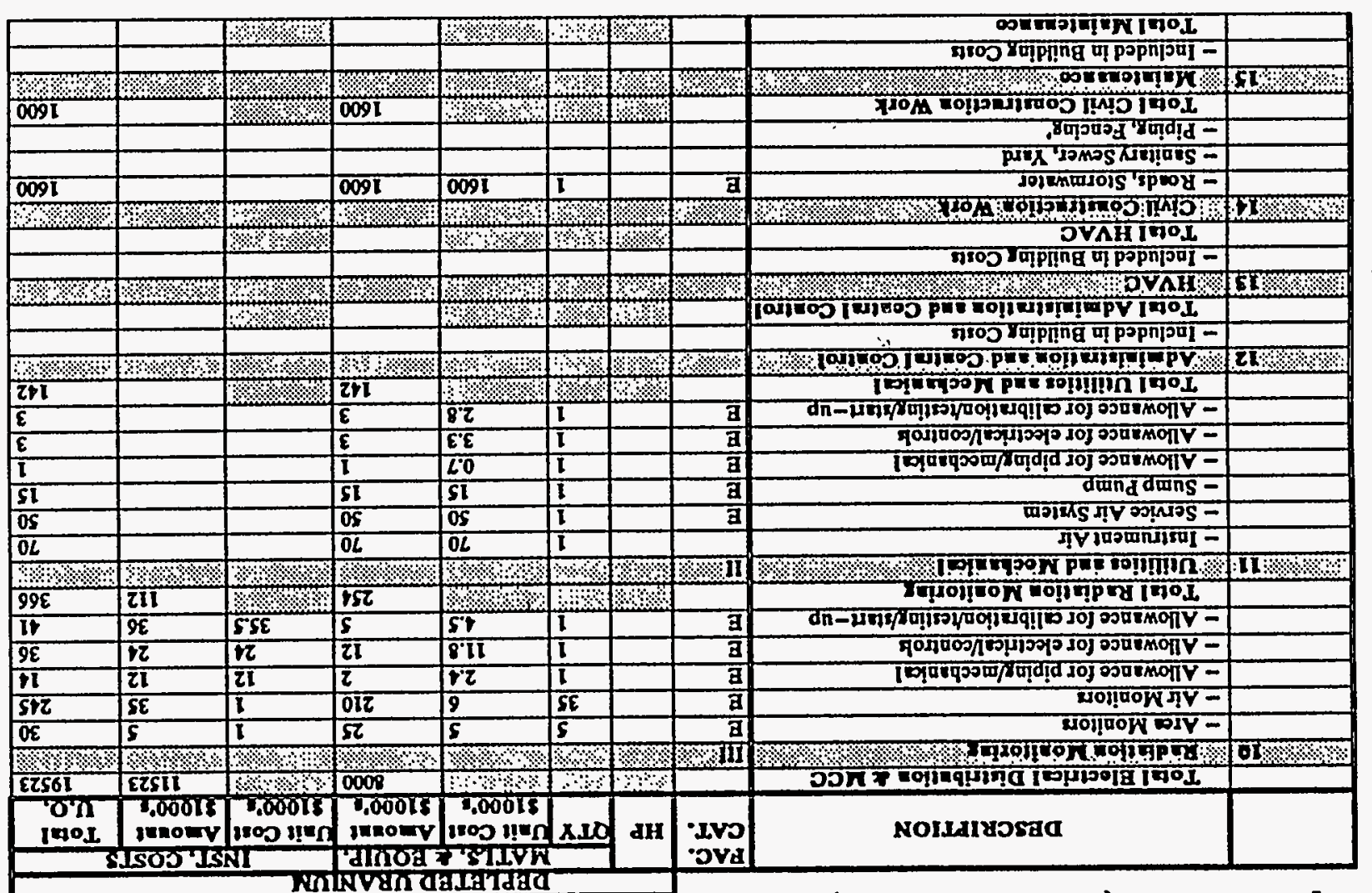

(s\&dna olnpow zroj) untursh pojojda - sejemigr 
Table A-2: Building and Equipment Material \& Installation Cost Estimate Summary Depleted Uranium (Cost Module DUPRS)

\begin{tabular}{|c|c|c|c|c|c|c|c|c|c|c|}
\hline & \multirow[b]{3}{*}{ UNIT OPERATION } & \multicolumn{9}{|c|}{ DEPLETED URANIUM } \\
\hline & & \multicolumn{5}{|c|}{ Building Area } & \multicolumn{3}{|c|}{ Material \& Equipment Costs } & \multirow{2}{*}{$\begin{array}{c}\text { Total } \\
\text { Cost per } \\
\text { Unit Oprtn. } \\
\$ 1000 \\
\end{array}$} \\
\hline & & $\begin{array}{l}\text { Cost } \\
\text { Category } 1 \\
\text { sq.ft }\end{array}$ & $\begin{array}{c}\text { Cost } \\
\text { Ca tegory } 2 \\
\text { sq.ft } \\
\end{array}$ & \begin{tabular}{|c|}
$\begin{array}{c}\text { Cost } \\
\text { Ca tegory } 3 \\
\text { sq.ft }\end{array}$ \\
\end{tabular} & \begin{tabular}{|c|} 
Cost \\
Category 4 \\
sq.ft \\
\end{tabular} & $\begin{array}{c}\text { Total } \\
\text { Arca Cost } \\
\$ 1000\end{array}$ & \begin{tabular}{|c|} 
Purchase \\
Cost \\
$\$ 1000$ \\
\end{tabular} & $\begin{array}{c}\text { Installation } \\
\text { Cost } \\
\$ 1000 \\
\end{array}$ & $\begin{array}{c}\text { Total } \\
\text { Cost } \\
\$ 1000\end{array}$ & \\
\hline 1 & Storage and Receiving & & & 7,000 & & 915 & 1112 & 450 & 1562 & 2477 \\
\hline 2 & Plasma Reactor & & & 2,800 & & 575 & 26455 & 14421 & 40876 & 41451 \\
\hline 3 & Metal/Gas Cooling \& Separation & 2,130 & & & & 96 & 2592 & 1310 & 3902 & 3998 \\
\hline 4 & HF and Hydrogen Gas Separation & 5,110 & & & & 230 & 1924 & 993 & 2917 & 3147 \\
\hline 5 & Uranium Metal Melting & 1 & & 2,400 & & 100 & 17932 & 9918 & 27850 & 27950 \\
\hline 6 & Uranium Metal Cutting \& Storage & & & 1,200 & & 50 & 579 & 309 & 888 & 938 \\
\hline 7 & Water Cooling System & 14,440 & & & & 650 & 5999 & 3224 & 9223 & 9873 \\
\hline 8 & Supply Hydrogen & & & & & & & & & \\
\hline 9 & Electrical Distribution \& MCC & & & & & & 8000 & 11523 & 19523 & 19523 \\
\hline 10 & Radiation Monitoring & & & & & & 254 & 112 & 366 & 366 \\
\hline 11 & Utilities and Mechanical & & & & & 90 & 142 & & 142 & 232 \\
\hline 12 & Administration and Central Control & & 3,900 & & & 470 & & & & 470 \\
\hline 13 & HVAC & & & & & & & & & \\
\hline 14 & Civil Construction Work & & & & & & 1600 & & 1600 & 1600 \\
\hline \multirow[t]{3}{*}{15} & Maintenance & & & 2,400 & & 288 & & & & 288 \\
\hline & Total Cost & $\therefore$ & , $\cdots$ & स $\quad \because$ & $\because \quad \therefore$ & 3,464 & & & 108,849 & 112,313 \\
\hline & & & Post Totals To & Table 4, Ite & & 2.4 .1 & & & 2.4 .2 & \\
\hline
\end{tabular}

01:47 PM 
Table A-3: Annual Operating \& Maintenance Costs Depleted Uranium (Cost Module DUPRS)

\begin{tabular}{|c|c|c|c|c|c|c|c|}
\hline & & & & & DEPLETED & URANIUM & \\
\hline & UNIT OPERATION & $\begin{array}{c}\text { Operating } \\
\text { FTE }\end{array}$ & $\begin{array}{c}\text { Utilities } \\
\$ 1000\end{array}$ & \begin{tabular}{|c|} 
Materials \\
$\$ 1000$
\end{tabular} & $\begin{array}{c}\text { Maintenance } \\
\text { Labor (1) } \\
\$ 1000\end{array}$ & $\begin{array}{c}\text { Maintenance } \\
\text { Materials (2) } \\
\$ 1000\end{array}$ & $\begin{array}{l}\text { Totals } \\
\$ 1000\end{array}$ \\
\hline 1 & Storage and Receiving & 10 & 44 & & 110 & 44 & 154 \\
\hline 2 & Plasma Reactor & 8 & 6344 & 727 & 2,645 & 1,058 & 3,703 \\
\hline 3 & Metal/Gas Cooling \& Separation & 4 & 67 & & 260 & 104 & 364 \\
\hline$\overline{4}$ & HF and Hydrogen Gas Separation & .2 & 67 & 1,008 & 193 & 77 & 270 \\
\hline 5 & Uranium Metal Melting & 4 & 269 & & 1,793 & 717 & 2,510 \\
\hline 6 & Uranium Metal Cutting \& Storage & 4 & 44 & & 58 & 23 & 81 \\
\hline 7 & Water Cooling System & 4 & 44 & & 600 & 240 & 840 \\
\hline$\overline{8}$ & Argon Gas & & 1710 & & & & \\
\hline 9 & Supply Hydrogen & & 359 & 116 & & & \\
\hline 10 & Electrical Distribution \& MCC & 4 & 44 & & 800 & 320 & 1,120 \\
\hline 11 & Radiation Monitoring & 2 & 44 & & 25 & 10 & 35 \\
\hline 12 & Utilities and Mechanical & 2 & 44 & & 15 & 6 & 21 \\
\hline 13 & Administration and Central Control & 25 & 44 & 175 & & & \\
\hline 14 & HVAC & & & & & & \\
\hline 15 & Civil Construction Work & & & & 160 & 64 & 224 \\
\hline 16 & Maintenance & & & & & & \\
\hline & Unit cost (\$/unit) & $\$ 140,000$ & & & & (2) & \\
\hline & Total Cost & 9,660 & 9123 & 2,026 & & & 9,322 \\
\hline & Post Totals To Table 4, Item & 4.1 & 4.2 & 4.3 & & & 4.4 \\
\hline
\end{tabular}

Notes: 01:48 PM

1. Annual Maintenance Labor is $250 \%$ of maintainence material cost.

2. Maintenance Material is assumed to be $7 \%$ of equipment capital cost.

3. Recycle of Ar based on membrane technology. Cost data supplied by Prax Air

For $1 \times 10^{6} \mathrm{SCFH}$ gas mixture comprised of $1 / 3 \mathrm{H}_{2}$ and $2 / 3 \mathrm{Ar}$, the capital cost would be $\$ 10-12$ million. Operating power requirements would be $6000 \mathrm{~kW}$.

For a 10 year lifetime, $15 \%$ interest, and $\$ 0.06 / \mathrm{kWh}$, this yields approximately $\$ 1.00 / 1,000$ SCF Ar produced. 
Table A-4: Decontamination \& Decommissioning Costs Depleted Uranium (Cost Module DUPRS)

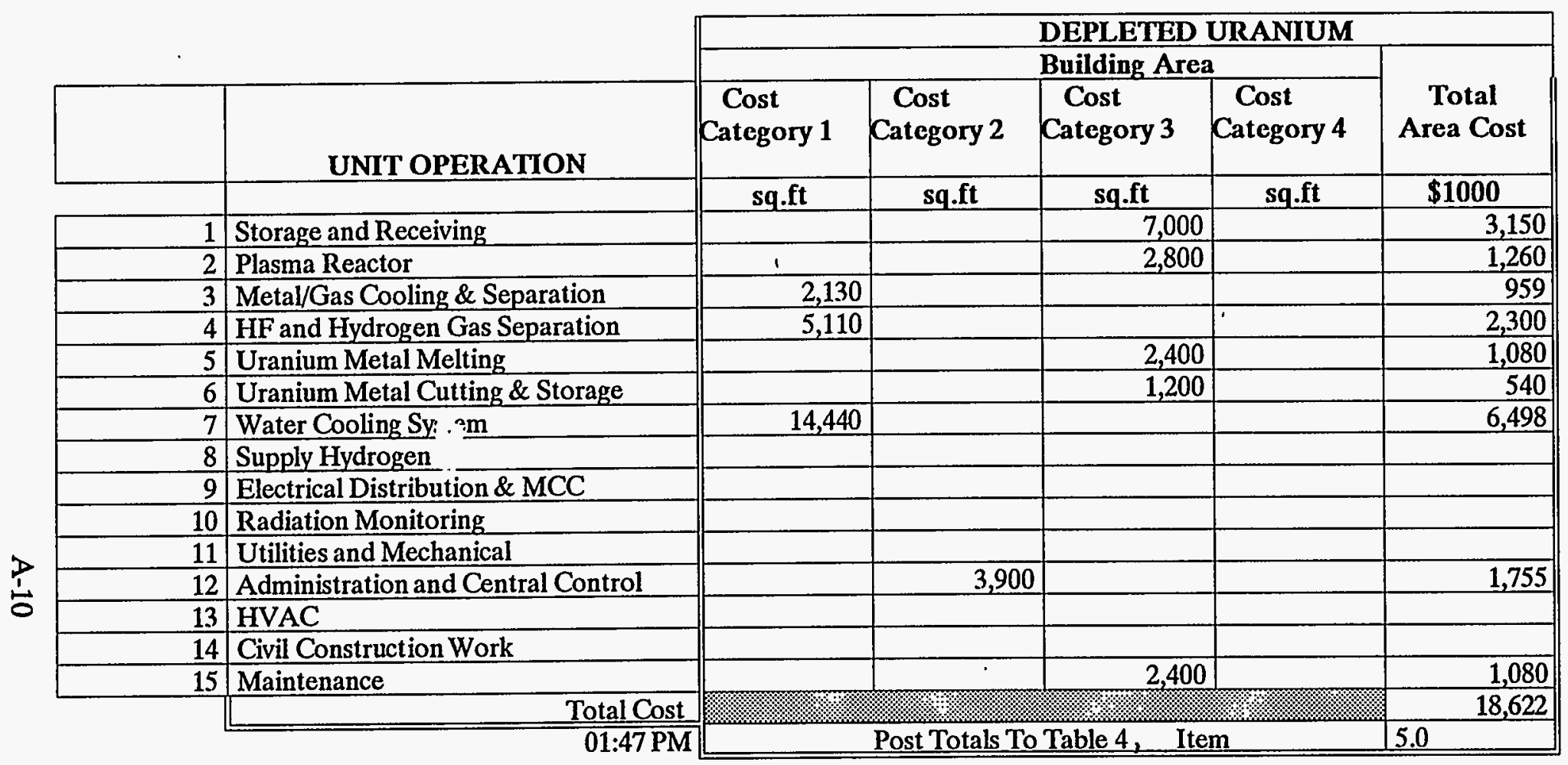


ThWo A-5: Pector Sthoot for -

Deplotod Urinion (Cot Modilo DUPRS)

FACTOR POR COSTS

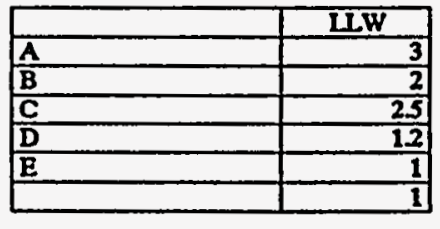

BUILDING UNTT RATE COSTS / ENGO AND O \& MLABOR COSTS/ DECOMMISSIONINO UNTT RATE COSTS

\begin{tabular}{|c|c|}
\hline COST CATEGORY 1 & \begin{tabular}{l|l} 
S45 & Bld s. Cost for Concrete Shab
\end{tabular} \\
\hline COST CATEGORY 2 & S180 Bde Cost for Administration \\
\hline COST CATEGORY 3 & S225 Bld Cost for all other Process Bldg. \\
\hline COST CATEGORY 4 & Not Uned \\
\hline DECONRATE & 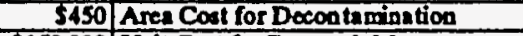 \\
\hline TRMRATE & 5150,000 Unit Cont lor Resenech Mappower \\
\hline MTDRATE & $\$ 150,000$ Unit Cost for Mock - up Test Demo \\
\hline FTERATE & $\$ 140,000$ Unit Cost for Operating PIE \\
\hline
\end{tabular}

COST PACTORS USED IN SUMMARY TABLE

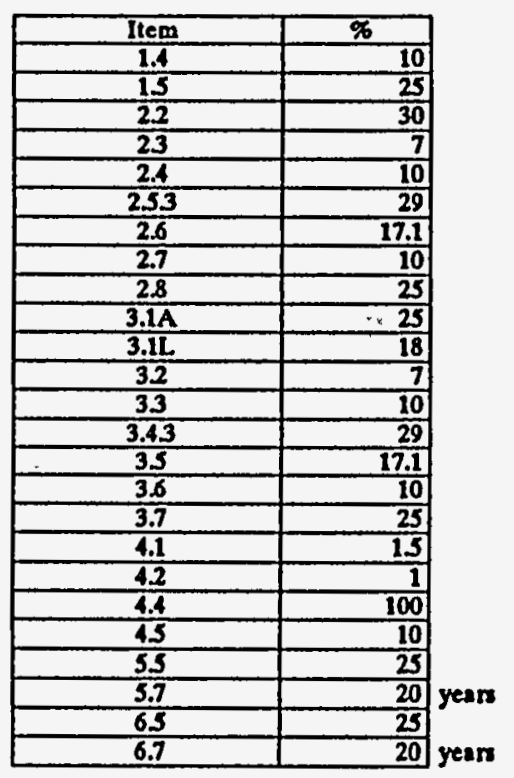

ALLOW ANCES POR EOUTPMENTTABLE

\begin{tabular}{|c|c|c|c|c|c|c|c|c|c|}
\hline \multirow[t]{2}{*}{ Calcgony } & \multirow[t]{2}{*}{ Mix } & \multicolumn{2}{|c|}{ Mochenical } & \multicolumn{2}{|c|}{ Moch/Piping } & \multicolumn{2}{|c|}{ Eloct/Const. } & \multicolumn{2}{|c|}{ Calib. Teating } \\
\hline & & $\begin{array}{l}\text { Mad. d } \\
\text { Equip. }\end{array}$ & $\begin{array}{l}\text { Inst. } \\
\text { Costs }\end{array}$ & $\begin{array}{l}\text { Mal. \& } \\
\text { Equip. }\end{array}$ & $\begin{array}{l}\text { Inst. } \\
\text { Costs }\end{array}$ & $\begin{array}{l}\text { Mad. \& } \\
\text { Equip. }\end{array}$ & $\begin{array}{l}\text { Inst. } \\
\text { Costs }\end{array}$ & $\begin{array}{l}\text { Ma1.\& } \\
\text { Equip. }\end{array}$ & $\begin{array}{l}\text { Inst. } \\
\text { Costs }\end{array}$ \\
\hline I & MHH Hondlin cranes, shredders & 5 & 50 & 5 & 50 & -5 & 30 & 2 & 30 \\
\hline II & Pumpa, Tanks, process oquipment & 10 & 70 & 10 & 70 & 7 & 50 & 2 & 50 \\
\hline III & Eoct. Cool. CCTV, Instruments Monitoring & 1 & 30 & I & 30 & $\underline{5}$ & 60 & 2 & 50 \\
\hline
\end{tabular}

